\title{
Nutrition, genetic variation and male fertility
}

\author{
Shelley M. Vanderhout ${ }^{1}$, Matineh Rastegar Panah $^{1}$, Bibiana Garcia-Bailo ${ }^{1}$, Patricia Grace-Farfaglia ${ }^{2}$, \\ Konrad Samsel $^{1}$, Judith Dockray ${ }^{3}$, Keith Jarvi ${ }^{3}$, Ahmed El-Sohemy ${ }^{1}$
}

${ }^{1}$ Department of Nutritional Sciences, University of Toronto, Toronto, ON, Canada; ${ }^{2}$ Department of Nutritional Sciences, University of Connecticut, Waterbury, CT, USA; ${ }^{3}$ Murray Koffler Urologic Wellness Centre, Department of Urology, Mount Sinai Hospital, Toronto, ON, Canada

Contributions: (I) Conception and design: SM Vanderhout, A El-Sohemy; (II) Administrative support: None; (III) Provision of study material or patients: None; (IV) Collection and assembly of data: SM Vanderhout, M Rastegar Panah, K Samsel, A El-Sohemy; (V) Data analysis and interpretation: SM Vanderhout, M Rastegar Panah, K Samsel, A El-Sohemy; (VI) Manuscript writing: All authors; (VII) Final approval of manuscript: All authors. Correspondence to: Ahmed El-Sohemy. 1 King's College Circle, Room 5326, Toronto, ON M5S 1A8, Canada. Email: a.el.sohemy@utoronto.ca.

\begin{abstract}
Infertility affects nearly 50 million couples worldwide, with $40-50 \%$ of cases having a male factor component. It is well established that nutritional status impacts reproductive development, health and function, although the exact mechanisms have not been fully elucidated. Genetic variation that affects nutrient metabolism may impact fertility through nutrigenetic mechanisms. This review summarizes current knowledge on the role of several dietary components (vitamins A, B 12 C, D, E, folate, betaine, choline, calcium, iron, caffeine, fiber, sugar, dietary fat, and gluten) in male reproductive health. Evidence of genenutrient interactions and their potential effect on fertility is also examined. Understanding the relationship between genetic variation, nutrition and male fertility is key to developing personalized, DNA-based dietary recommendations to enhance the fertility of men who have difficulty conceiving.
\end{abstract}

Keywords: Micronutrients; reproduction; fertility; nutrition; genetics; nutrigenomics; nutrigenetics

Submitted Feb 19, 2020. Accepted for publication Jun 20, 2020.

doi: $10.21037 / \mathrm{tau}-20-592$

View this article at: http://dx.doi.org/10.21037/tau-20-592

\section{Introduction}

Infertility is defined by the World Health Organization as "a disease characterized by the failure to establish a clinical pregnancy after 12 months of regular, unprotected sexual intercourse" (1). Although the causes of infertility are often complicated and difficult to identify, health and lifestyle factors affect the ability of both men and women to reproduce. In men, abnormalities in sperm count, morphology and motility all have an impact on successful fertilization (2). Oxidative stress, which is an imbalance between oxygen-derived free radicals and antioxidants leading to cell damage, has also been identified as a factor which may affect sperm quality and fertilization potential (3).

Nearly 50 million couples worldwide experience infertility (4,5). According to the 2009-2010 Canadian Community Health Survey, estimates of the prevalence of infertility in Canada range from $10 \%$ to $15.5 \%$ of couples (6). Male factor infertility accounts for $20-30 \%$ of total cases, with an additional $20-30 \%$ being due to a combination of male and female factor infertility (7).

There is mounting evidence to suggest a relationship between various dietary components and fertility. While adherence to a prudent diet appears to be protective for fertility in both men and women, results from randomized controlled trials (RCTs) on the effect of specific antioxidant and micronutrient supplements are less consistent (8-10). The inconsistent results from supplementation studies may be due, in part, to genetic differences in absorption, distribution, metabolism and excretion of specific dietary components. However, little research to date has examined how genetic variation modifies the relationship between diet and fertility. Ultimately, knowledge of an individual's genotype could lead to the development of tailored nutritional recommendations to optimize fertility. The present review summarizes the evidence on the relationships 
Table 1 Overview of the potential impact of genetic variation in micronutrient metabolism on male fertility

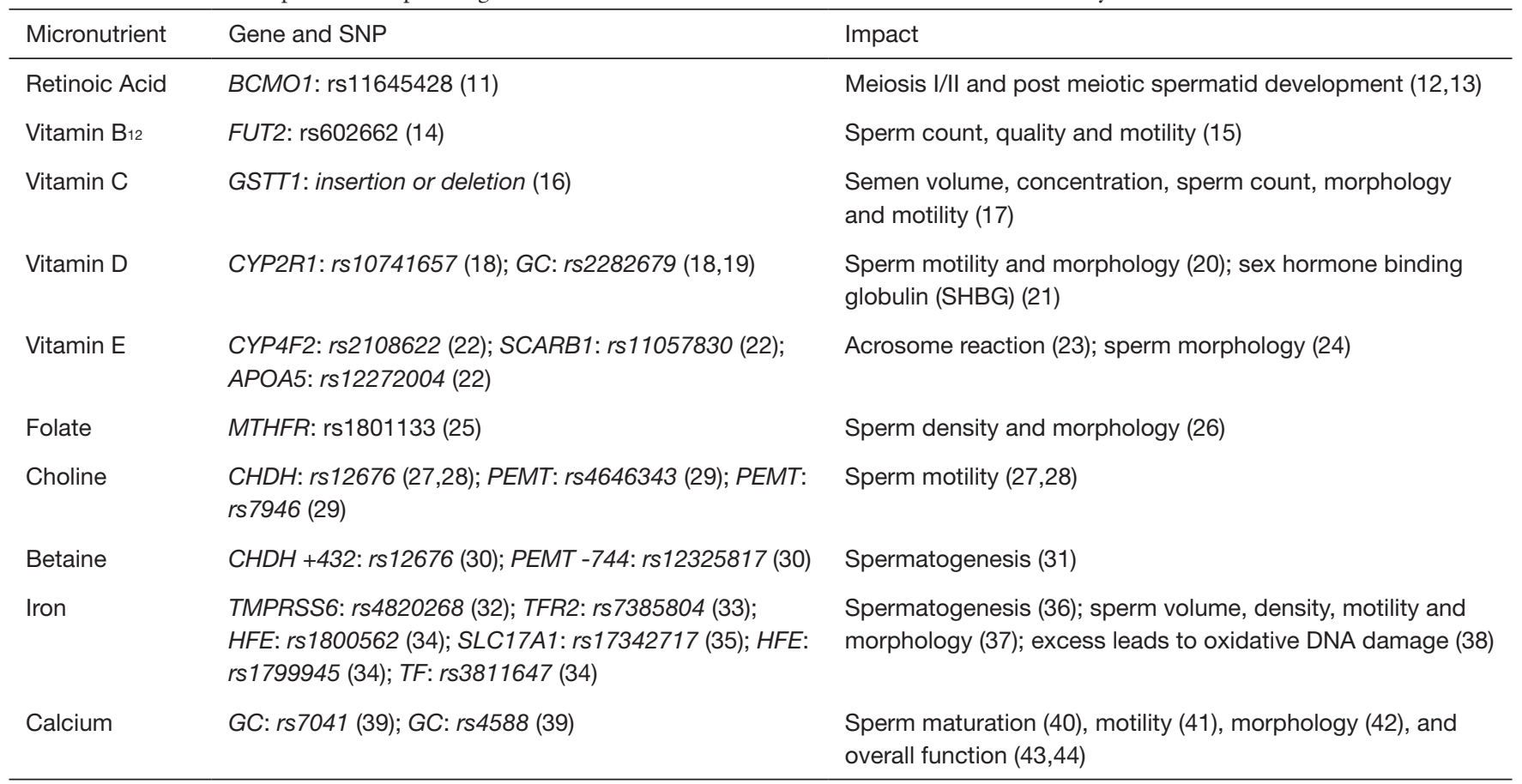

between specific dietary components (micronutrients, macronutrients, and other food bioactives) and fertility in men. The potential effects of genetic variation on these relationships are discussed (summarized in Tables 1,2).

\section{Micronutrients and male fertility}

\section{Vitamin A}

Vitamin A plays an important role in both male and female reproductive health. Vitamin A supports the immune system, which mediates reactive oxygen species (ROS) activity and thus protects the gonads and reproductive tissues from oxidative stress (68). Vitamin A circulates in two main forms in the body: beta-carotene (inactivated) and retinol (activated). Retinoic acid, another vitamin A metabolite, may play a role in male fertility via its influence on regulation of sperm morphology and concentration (Figure 1) (68-70).

Retinoic acid induces spermatogenesis during early development and throughout childhood (71). Higher serum retinol has been observed in men with normozoospermia compared to those with oligospermia, asthenozoospermia, and azoospermia (68). With a deficiency of retinoic acid, the blood-testis barrier (BTB) is compromised by halting meiosis I/II and post-meiotic spermatid development, which occurs behind the immunological BTB $(12,13)$. Vitamin A deficiency damages the seminiferous epithelium of the epididymis, prostate, and the seminal vesicle, which results in the termination of spermatogenesis (71). Despite vitamin A deficiency leading to early cessation of spermatogenesis, one recent study found that long-term chronic excessive intake of vitamin A impairs sperm production, morphology, motility and viability in mice (72).

The beta-carotene mono-oxygenase 1 (BCMO1) enzyme, which is encoded by the BCMO1 gene, converts circulating beta-carotene to retinol (Figure 1). It has been shown that about $70 \%$ of individuals possess the GG variant of the BCMO1 (rs11645428) gene (73), which is associated with inefficient conversion of beta-carotene to retinol (11). Two genes that play a role in spermatogenesis in humans, STRA8 and REC8, are both induced by retinoic acid (74). Sequence variants in genes encoding tight junction proteins that fortify the BTB have yet to be identified. Further studies are needed to identify all proteins involved in vitamin A metabolism, sperm development and vitality. Additional human studies exploring toxicity of excessive vitamin A intake on male fertility parameters are also needed. 
Table 2 Overview of the potential impact of genetic variation in metabolism of macronutrients and other food bioactive ingredients on male fertility

\begin{tabular}{|c|c|c|}
\hline Dietary component & Gene and SNP & Impact \\
\hline Saturated fat & APOA2: rs5082 (55) & $\begin{array}{l}\text { Elevated BMI; sperm count, concentration, motility, } \\
\text { morphology }(56,57)\end{array}$ \\
\hline Sugar & GLUT2: rs5400 (58) & Sperm motility and count (59) \\
\hline Fiber & TCF7L2: rs12255372 (60) & $\begin{array}{l}\text { Low fiber diet can lead to insulin resistance and type } \\
2 \text { diabetes, negatively impacting spermatogenesis, } \\
\text { sperm maturation (61) }\end{array}$ \\
\hline Gluten & $\begin{array}{l}\text { HLA: rs2395182, rs7775228, rs2187668, } \\
\text { rs4639334, rs7454108, rs4713586 (62) }\end{array}$ & $\begin{array}{l}\text { Androgen resistance (63); sperm morphology and } \\
\text { motility (64) }\end{array}$ \\
\hline
\end{tabular}

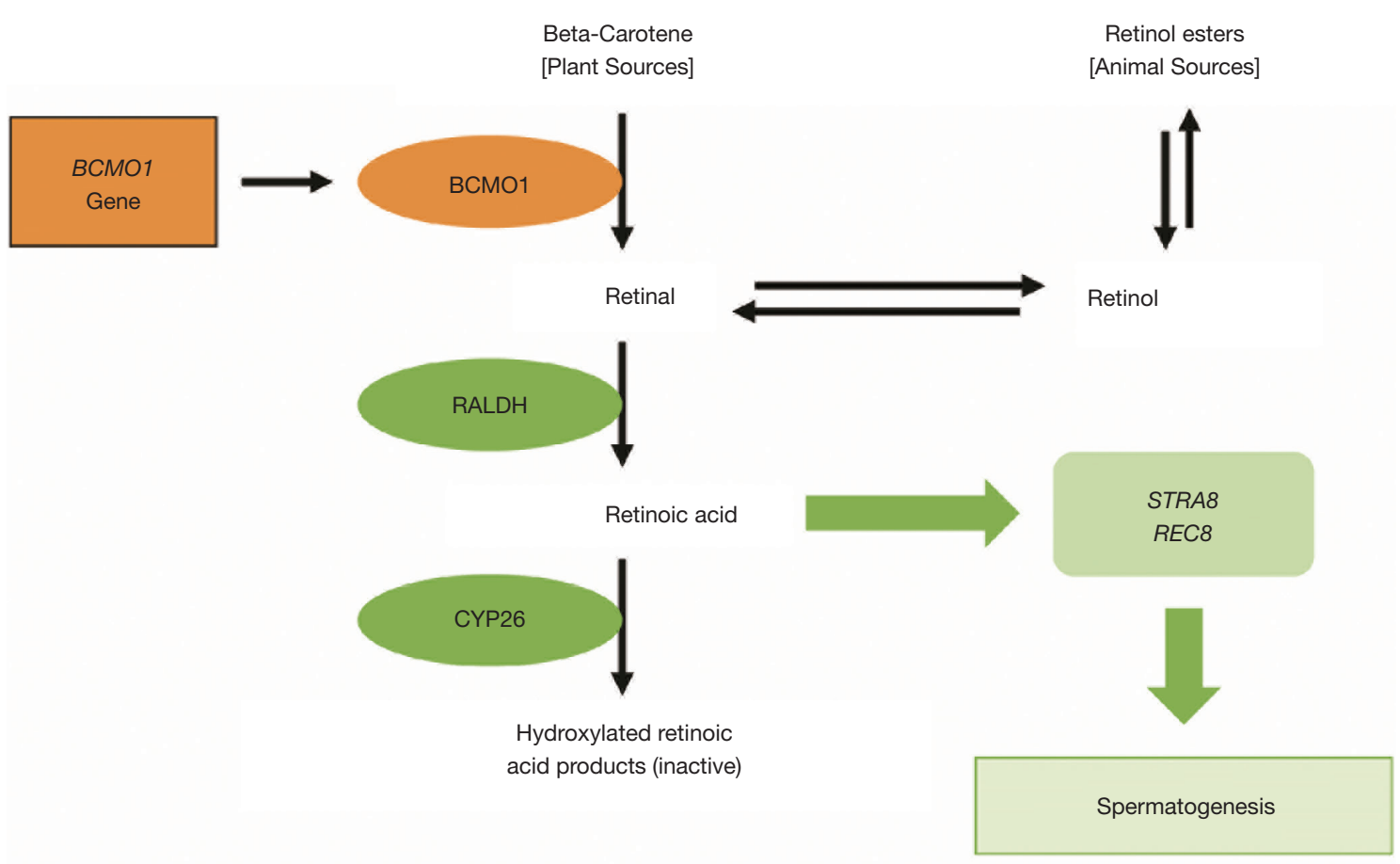

BCMO1 - Beta-carotene mono-oxygenase 1

RALDH - Retinaldehyde dehydrogenase

CYP26 - Cytochrome P450-26

Figure 1 Vitamin A metabolic pathway. Beta-carotene mono-oxygenase 1 (BCMO1) converts circulating beta-carotene to retinal (aldehyde), the aldehyde form is then converted into retinoic acid. Retinoic acid induces STRA 8 and REC 8 expression, which aids in spermatogenesis. 


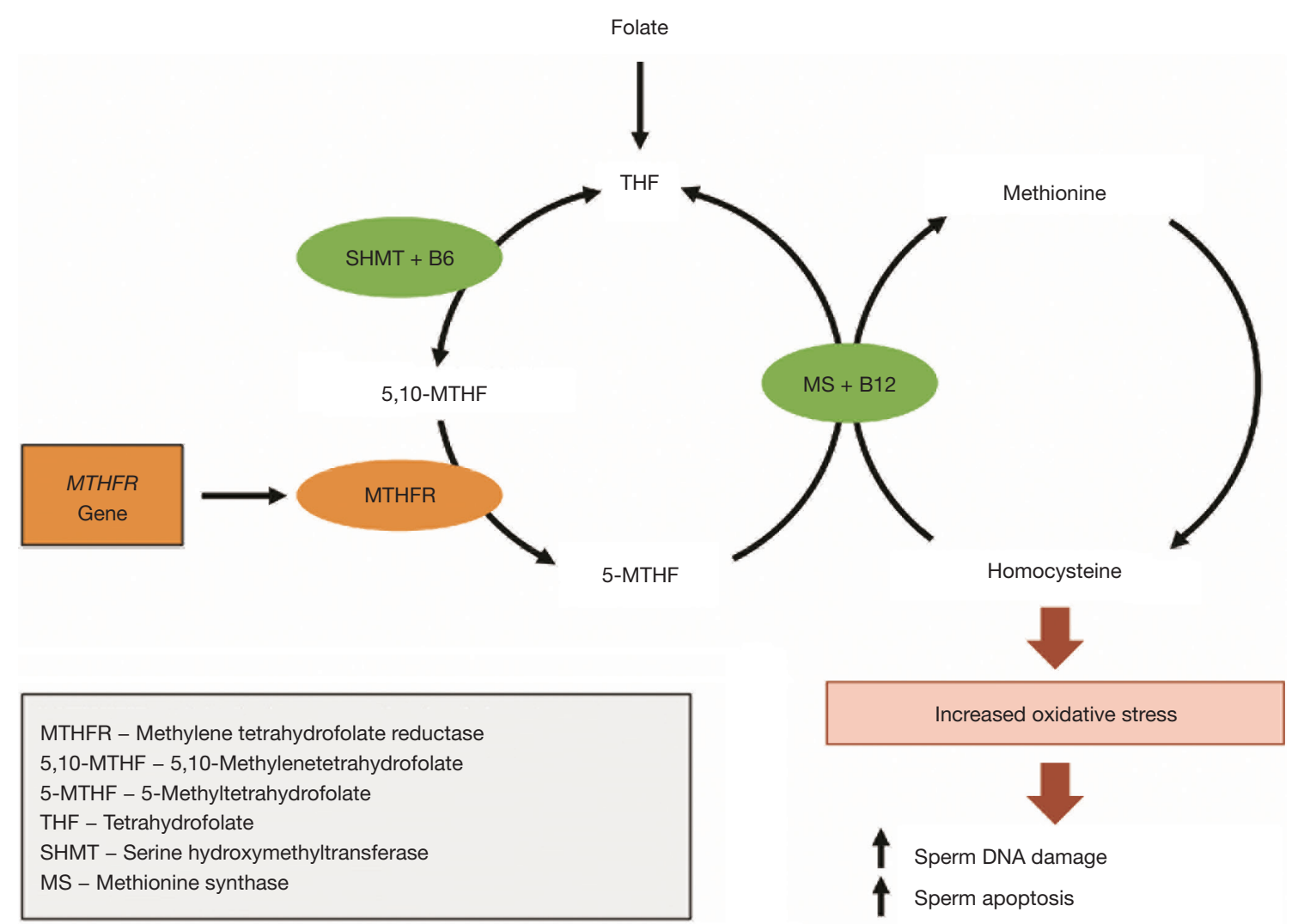

Figure 2 Folate metabolic pathway. Methylene tetrahydrofolate reductase converts 5,10-methylenetetrahydrofolate, an intermediate in the folate metabolic cycle, to 5-methyltetrahydrofolate (5-MTHF). 5-MTHF is a methyl group donor in the conversion of homocysteine to methionine.

\section{Vitamin $B_{12}$}

Vitamin $\mathrm{B}_{12}$, in combination with folate, plays an integral role in the remethylation cycle of homocysteine (Hcy) to methionine (Met) (Figure 2) (75). Circulating homocysteine concentrations have been positively associated with oxidative stress (76). Vitamin $B_{12}$ acts as a cofactor to the enzyme methylene-tetrahydrofolate-reductase, which catalyzes the remethylation of homocysteine to methionine (77). Hyperhomocysteinemia, a condition associated with poor in-vitro fertilization outcomes and reduced sperm concentration, quality (DNA fragmentation index) and motility (78-80), is most often attributable to low folate and vitamin $\mathrm{B}_{12}$ levels (80).

In addition to vitamin $B_{12}$ obtained from food, the stability of human plasma concentrations depends on gut de novo microbial biosynthesis and transport (81). In humans, the fucosyltransferase 2 (FUT2) enzyme is regulated by the FUT2 gene and is responsible for vitamin $\mathrm{B}_{12}$ homeostasis and transport throughout the body. Variation in the FUT2 gene is associated with differing levels of circulating vitamin $\mathrm{B}_{12}$. Indeed, the GG variant of FUT2 (rs602662) is linked to lower plasma vitamin $B_{12}(14)$ and has been observed in about $50 \%$ of the population (82). Since dietary vitamin $\mathrm{B}_{12}$ is only naturally derived from animal food sources, vegetarians and vegans are at an increased risk of vitamin $\mathrm{B}_{12}$ deficiency if supplementation does not occur, and this risk is even greater among those with the GG genotype for FUT2 rs602662 (14). The relationship between vitamin $\mathrm{B}_{12}$ intake and fertility may, therefore, be partly mediated by the FUT2 genotype.

Circulating vitamin $\mathrm{B}_{12}$ levels also correlate with sperm concentration, motility, morphology and sperm DNA damage (15). Low plasma levels of vitamin $B_{12}$ have been associated with male infertility (83). Few studies have reported on the role of dietary $\mathrm{B}_{12}$ on semen parameters in humans $(80,84)$. Recent in vitro evidence has shown that 
$\mathrm{B}_{12}$ insufficiency resulting in hyperhomocysteinemia creates a toxic environment which reduces both sperm count and motility (85). Overall, the available evidence emphasizes the importance of vitamin $B_{12}$ in male reproductive health through its role in Hcy metabolism and nucleic acid synthesis.

\section{Vitamin C}

Vitamin C, or ascorbic acid, has various physiological functions including aiding in tissue and hormone development, acting as a co-factor for enzymes and reducing oxidative damage via its role as a powerful antioxidant (86). Enzymes called glutathione S-transferases, or GSTs, are responsible for maintaining the glutathione-ascorbic acid antioxidant cycle. The GSTT1 enzyme aids in the conversion of dehydroascorbic acid into ascorbic acid, and is encoded by the glutathione S-transferase T1 gene (GSTT1). Variation in this gene, specifically, possessing two copies of the deletion variant of GSTT1, which has been observed in $20-40 \%$ of the population, depending on ethnicity (35), can impair GSTT1 enzymatic activity (87). GSTT1 genotype influences the relationship between dietary intake of vitamin $\mathrm{C}$ and circulating ascorbic acid. Individuals homozygous for the deletion variant of GSTT1 are at a much greater risk of being deficient when they do not meet the recommended daily allowance (RDA) for vitamin C (16). Results from a small $(\mathrm{N}=24)$ two-week intervention providing a high fruit juice and vegetable antioxidant-rich diet in healthy males and females with varying glutathione-S-transferase (GST) genotypes showed evidence of an increase in GST activity in the GSTT1+ group compared to baseline and the GSTT1group (16). There was evidence that plasma vitamin C levels in the GSTT1 deletion group were different from baseline, while there was no difference in total antioxidant capacity or retinol levels. Dietary intake did not differ between groups, leading to the conclusion that response to the diet varied by genotype. Therefore, it may be especially important for individuals who are homozygous for the deletion variant of GSTT1 to meet the vitamin C RDA for both overall and reproductive health.

Vitamin C intake has been positively associated with healthy semen parameters, as dietary intake influences seminal ascorbic acid concentrations (88). Seminal ascorbic acid concentrations can measure up to 10 times that of serum ascorbic acid (89) and have been shown to protect against oxidative damage to sperm DNA when sufficient (90). Ascorbic acid may account for $65 \%$ of seminal antioxidant activity (91) and affects the integrity and structure of sperm by promoting an environment where sperm can thrive, develop and reproduce, minimizing structural and functional flaws (86). Despite some studies showing no benefit of vitamin C to sperm quality (92-94), other studies including RCTs have supported a positive association between vitamin $\mathrm{C}$ intake, serum and semen ascorbic acid concentrations, and healthy semen parameters including semen volume, and sperm concentration, number, motility and morphology, and overall fertility (95). Higher dietary vitamin $\mathrm{C}$ intake has been linked to reduced sperm DNA damage (90,96-98) and low levels of seminal vitamin $C$ have been associated with higher sperm DNA fragmentation in infertile men (99).

Variation in the GSTT1 gene influences susceptibility to deficiency of vitamin C (16). Despite the evidence for beneficial effects of vitamin $\mathrm{C}$ on male fertility, consuming an excess amount of vitamin $\mathrm{C}$ poses the risk of promoting oxidative stress by acting as a pro-oxidant (100). Further research is needed to determine concentrations at which this effect occurs (101).

\section{Vitamin D}

Vitamin D has a well-known role in bone health through modulation of calcium metabolism as well as a variety of other proposed functions such as immune and inflammatory modulation and reproductive system regulation $(102,103)$. Vitamin D can be obtained through the diet and through endogenous production after exposure to sunlight (104). To exert its biological functions, both dietary and endogenous vitamin $\mathrm{D}$ must be activated to 1,25-hydroxyvitamin $\mathrm{D}$ by the enzyme vitamin D 25-hydroxylase (105), which is regulated partly by the CYP2R1 gene (18). Activated vitamin $\mathrm{D}$ is transported throughout the body by the vitamin $\mathrm{D}$ binding protein (DBP), which is encoded by the $G C$ gene (18). Certain variants of both genes impact functioning of both vitamin D 25-hydroxylase and DBP, such that individuals who possess the GG or GA variant of CYP2R1 (rs10741657), and/or the GG variant of GC (rs2282679), together prevalent in over $80 \%$ of the population $(106,107)$, have an increased risk of lower circulating vitamin $\mathrm{D}(18,19)$.

The biologically active 1,25-hydroxyvitamin D binds to target genes via the vitamin D receptor (VDR), triggering their transcription and subsequent physiological effects (108). The VDR and the 25-hydroxyvitamin D metabolizing enzyme $1 \alpha$-hydroxylase (CYP27B1) have active roles in sperm motility. CYP24A1 expression has also been 
identified as a differential marker for sperm quality (109). VDRs are present in the testicular Leydig cells, epididymis, prostate, seminal vesicles and sperm (110), suggesting a need for vitamin $\mathrm{D}$ in such tissues for spermatogenesis and sperm maturation $(109,111)$. Vitamin D modulates cholesterol and triglycerides in sperm head membranes, which are important for the protection of sperm DNA, and may potentially have an impact on sperm viability, motility, and fertilization capacity $(110,112)$. Vitamin D's role in maintaining calcium homeostasis may also contribute both to motility and to the acrosome reaction, which potentiates fertilization $(20,113,114)$. Human studies analyzing circulating vitamin $\mathrm{D}$ and semen parameters are less common than rodent models, but some have shown that serum 25-hydroxyvitamin D concentrations correlate positively with sperm motility and normal morphology (20) as well as circulating testosterone levels (115-117). However, there appears to be a U-shaped relationship between serum vitamin $\mathrm{D}$ and androgen concentrations, where both deficiency and excess may be associated with adverse reproductive outcomes (118).

In a RCT investigating the effects of dietary supplementation on sperm motility in men with idiopathic oligoasthenozoospermia, eighty-six participants were divided into two equal groups and given 200 IU vitamin D and $600 \mathrm{mg}$ calcium daily, or $100 \mathrm{mg}$ vitamin $\mathrm{E}$ and $100 \mathrm{mg}$ vitamin C daily for 3 months (119). There was evidence that sperm count per ejaculate increased in the calcium/vitamin D group, while there was no evidence of a difference in the lower dose supplementation group from baseline. The calcium/vitamin D group achieved pregnancy in $16.3 \%$ of cases, compared to $2.3 \%$ in the vitamin E/vitamin C group. Another RCT of 300 infertile men in Denmark investigated the effect of 1,400 IU vitamin D and $500 \mathrm{mg}$ calcium daily for 5 months on male infertility by analyzing the relationship between serum 25-hydroxyvitamin D concentration with ionized calcium on testicular function (120). The baseline characteristics suggested that infertile men with vitamin D deficiency had fewer motile sperm, lower sex hormone binding globulin (SHBG) and a lower testosterone/ estradiol ratio. Men with serum 25-hydroxyvitamin D $>75 \mathrm{nmol} / \mathrm{L}$ [considered sufficient (121)] had higher sperm motility compared to men with serum 25-hydroxyvitamin $\mathrm{D}<25 \mathrm{nmol} / \mathrm{L}$ [considered deficient (121)]. However, the study showed that there was no evidence of an association between vitamin $\mathrm{D}$ supplementation and sperm parameters (morphology, motility and DNA fragmentation) between the two study groups or in comparison to baseline within each group. The noted difference in hormone profiles were higher free testosterone and estradiol and lower SHBG levels in men with serum 25 -hydroxyvitamin $\mathrm{D}<25 \mathrm{nmol} / \mathrm{L}$. Furthermore, higher spontaneous pregnancy rates were seen in couples with the male in the vitamin D/calcium supplementation group. Lower calcium intake levels were associated with higher sperm motility and a more favourable hormone profile (21).

A study compared serum 25-hydroxyvitamin D with serum 1,25-dihydroxyvitamin D levels in males with fertility and infertility (122), and results showed no evidence of an association between serum 25-hydroxyvitamin D concentrations and semen parameters, but there was evidence of an association between higher 1,25-dihydroxyvitamin D concentrations and improved sperm motility and total sperm count in infertile men. This suggests 1,25-dihydroxyvitamin D concentration may potentially have a stronger association with sperm parameters in comparison to circulating 25-hydroxyvitamin D.

\section{Vitamin E}

Vitamin E, or alpha tocopherol, is a vital antioxidant in the cell membrane supporting reproductive function in men. It has been observed that there is inter-individual variability in the metabolism of $\alpha$-tocopherol in humans and mice fed vitamin E-enriched diets (123). Bioavailability of vitamin $\mathrm{E}$ varies by age, gender, absorption, catabolism and the presence of other nutrients, such as vitamin K (124). Single nucleotide polymorphisms (SNPs) associated with variation in vitamin $\mathrm{E}$ status encode for cytochrome P450 4F2 (CYP4F2), a plasma membrane receptor for HDL which is involved in tissue uptake (SCARB1), and genetic variance in APOA5 (22).

In men, sperm membranes are composed of cholesterol, phospholipids, and polyunsaturated fatty acids (125). Appropriate distribution and proportion of these components are integral to the function and vitality of sperm. As an antioxidant and protector of sperm membrane lipids, vitamin $\mathrm{E}$ is important in promoting motility and proper morphology of sperm (24), as well as fertilization within the acrosome reaction (23). Dietary vitamin $\mathrm{E}$ correlates with both serum and seminal alphatocopherol levels $(126,127)$, which are positively related to fertility (128) and normal sperm parameters (68). RCTs have shown improved sperm motility and reduced lipid peroxidation in sperm as a result of vitamin $\mathrm{E}$ and selenium supplementation $(126,127)$, which was also associated with 
greater chance of clinical pregnancy (24). Further research is needed on the combination of genetic factors that predicts vitamin $\mathrm{E}$ status and its effect on semen parameters and fertility.

\section{Folate}

Folate, or vitamin $\mathrm{B}_{9}$, is best known for its preventative effects on the development of neural tube defects (NTDs) in a fetus during the early stages of pregnancy (129). The methylene tetrahydrofolate reductase (MTHFR) enzyme is one of the enzymes involved in converting folate to 5 -methyltetrahydrofolate, which is a methyl group donor in the conversion of Hcy to Met (Figure 2) (130). The MTHFR gene regulates MTHFR enzyme activity (131). A common variant of the gene is the 677TT genotype, which affects approximately $40 \%$ of the population (132), is associated with reduced capacity to methylate DNA, lower levels of circulating folate and higher serum Hcy concentrations (25).

Low levels of serum and seminal folate can result in high levels of Hcy, which may induce oxidative stress, sperm DNA damage and apoptosis lowering sperm counts $(78,79,133)$. Though some studies have shown no relationship between folate intake and semen quality (134-137), others suggest a positive effect of folate intake on male reproductive health. Folate supplementation has been positively associated with lower sperm injury (98), higher sperm density, normal sperm morphology (80), overall higher semen quality (26) and negatively associated with infertility (84). RCTs have shown that folate supplements increase sperm concentration $(136,138)$ and motility (139) among men.

The MTHFR gene has been associated with fertility in men. Specifically, the 677TT genotype has been associated with infertility (140), azoospermia (80,141-143), sperm DNA fragmentation, and spontaneous abortion (144). Low sperm concentration related to possession of the 677TT genotype can be improved with folate supplementation (134). Thus, adequate folate intake may play a part in offsetting the effect of MTHFR genotype on semen parameters. A study investigating the relationship between Hcy and MTHFR SNP carriers emphasized the importance of analysis in couples experiencing infertility is important. The study concluded that physiological doses of 5-MTHFR are more effective than high doses of folic acid in reducing Hcy levels and improving the methylation process for MTHFR SNP carriers (145).

\section{Choline}

Choline is an essential nutrient found in a variety of foods in the diet, with high concentrations found in animalbased products such as liver, eggs, and wheat germ (146). It is present in dietary sources in both hydrophilic and lipophilic forms, which affect absorption and metabolism within the body (147). Despite being an essential nutrient, intake for women and men frequently falls below the recommended adequate intake level (148). Choline is an important source of one carbon (1C) units for DNA methylation (149) and is critical for regulation of gene expression as well as for the biosynthesis of lipoproteins and membrane phospholipids (150). Single nucleotide polymorphisms in the choline metabolizing gene choline dehydrogenase $(\mathrm{CHDH})$ are associated with greater risk for infertility. It has been reported that men with a genetic variation in $C H D H$ (rs12676) had reduced sperm motility or asthenospermia $(27,28)$. SNPs in folate and choline metabolizing genes increase the need for dietary choline by favoring phosphatidylcholine (PC) biosynthesis via the cytidine diphosphate-choline pathway $(29,151)$. As phosphatidylethanolamine N-methyltransferase (PEMT) catalyzes the synthesis of choline, PEMT variants rs 4646343 and rs7946 also affect endogenous phosphatidylcholine homeostasis (29).

\section{Betaine}

Betaine is a naturally occurring amino acid found in high concentrations in seafood and whole wheat products (152). This nutrient functions to protect cells from environmental stressors, including differences in osmolarity and temperature, and is a methyl donor in the Hcy-Met cycle (152). Betaine consumption in animal studies have been shown to raise sperm density and improve spermatozoa quality, with these effects occurring on a timespan shorter than one spermatogenic cycle (153).

Circulating betaine concentration depends on both folate and choline metabolism, and betaine status can be impacted by polymorphisms through two pathways: choline dehydrogenase, CHDH (+432 G $\rightarrow \mathrm{T}$; rs12676) and phosphatidylethanolamine N-methyltransferase (PEMT; -744 G $\rightarrow \mathrm{C}$; rs12325817) genes (30). Studies of MTHFR knockout mice have found a beneficial effect of betaine on spermatogenesis (31), and in folate deficiency, both betaine and choline supplementation prevent DNA 
hypomethylation (154). In humans, the consumption of a varied and balanced diet with adequate supply of both choline and betaine may mitigate loss of activity in the CHDH pathway on fertility (155).

\section{Iron}

Iron is an essential nutrient for the maintenance of healthy red blood cells, oxygen transport in the blood, immune function and free radical homeostasis (156). Deficiency can lead to impaired immune function and compromised oxygen availability to bodily tissues (156); however, iron in excess can act as a pro-oxidant and cause iron overload, in which iron deposits in tissues, impairing their function (157).

Iron is essential to ejaculate fluidity and maintaining sperm $\mathrm{pH}$ within a functional range (158). In addition, Sertoli and Leydig cells are sources of ferritin, an iron transport protein, to developing sperm. Ferritin also protects testicular tissue $(159,160)$. Furthermore, mitochondrial redox reactions create ATP, which support spermatogenesis and contribute to sperm motility, but require oxygen to occur $(161,162)$. Iron deficiency anemia, a manifestation of low serum iron, results in reduced circulatory oxygen transport and therefore creates a hypoxic environment to the testes (36). Individuals with health conditions leading to low serum iron such as sickle cell disease often have compromised fertility; men with the condition are known to have reduced ejaculate volume, sperm density, motility, and morphology (37). However, it is difficult to attribute compromised fertility parameters to low serum iron alone.

Though dietary iron relates to individual iron status, individual variation may in part be controlled by genes that regulate iron absorption and transport in the body, specifically TMPRSS6, TFR2 and TF genes. The transmembrane protease, serine 6 (TMPRSS6) gene codes for matriptase-2, a protein that influences hepcidin, which controls iron absorption at the gut epithelium. The transferrin receptor 2 (TFR2) gene regulates the TFR2 protein that aids in iron transport across cell membranes, and the transferrin $(T F)$ gene codes for transferrin, which carries iron in the blood. Variation in each of these genes can cause reduced functioning of the proteins they code for, which collectively can impact individual risk for low iron status (32-34). Individuals with variants of these genes that increase risk of iron deficiency may require higher dietary iron, or supplemental iron.

Conversely, genetic variation in the human hemochromatosis, or $H F E$, and sodium-dependent phosphate transport protein 1 (SLC17A1) genes can alter coding of HFE and SLC17A1 proteins, which also influence gut absorption of iron and risk of iron overload $(33,35,163)$. Iron overload poses risk for detrimental effects to the male reproductive system. Excess iron levels in seminal plasma have been associated with teratozoospermia and decreased motility, with the proposed mechanism being increased levels of reactive oxygen species leading to lipid peroxidation (164). Additionally, high levels of testicular iron are associated with impaired spermatogenesis (159), as well as direct damage to sperm (165). Iron deposits in the pituitary gland can lead to lower levels of testosterone (166). Further, any antioxidant in high quantities can exhibit pro-oxidative effects. Iron can cause oxidative damage to sperm DNA (38), and impair spermatogenesis and fertility in excess $(167,168)$. Those possessing genetic variants that increase risk of iron overload are advised not to over-consume iron rich foods and should avoid combining iron- and vitamin C-containing foods as the presence of an acid helps keep iron in its more soluble ferrous form $\left(\mathrm{Fe}^{2+}\right)$ (169). Additionally, individuals at risk for iron overload may be recommended to make dietary changes from sources of heme to non-heme iron, which is absorbed less efficiently than heme iron. Both low iron status and iron overload are conditions that can adversely impact the reproductive system. Monitoring dietary and genetic factors can help to achieve iron homeostasis.

\section{Calcium}

Calcium is important for a variety of functions in the body including promoting bone health, heart function, blood clotting and muscular contractions (170). It also plays a role in reproductive health due to its effects on vitamin D homeostasis, inflammation, and facilitating fertilization (171). Circulating calcium levels and, therefore, calcium available to reproductive tissues can be determined in part by individual genetic differences. The $G C$ gene encodes vitamin D-binding protein, which helps regulate vitamin $\mathrm{D}$ absorption and transport. This affects circulating calcium levels since vitamin $\mathrm{D}$ is necessary for its metabolism and homeostasis. Individuals with the G allele of $G C$ rs7041 and C allele of $G C$ rs4588, which affects approximately $60 \%$ of the population $(172,173)$, are at a higher risk for low circulating vitamin $\mathrm{D}$, which is associated with lower circulating calcium, when calcium intake is low (39).

In men, calcium is known to regulate sperm motility (174) 
and is responsible for triggering the acrosome reaction, which allows for effective fertilization $(175,176)$. Epididymal and prostate fluid contains 2-3 times the amount of calcium found in serum (177), suggesting its essence in sperm development and function. Though the mechanism through which calcium regulates fertility in men is not fully known, it has been demonstrated that vitamin $\mathrm{D}$ deficient mice that become hypocalcemic can restore fertile capabilities with calcium supplements only $(171,178)$. This may be due to the positive effect of calcium on sperm maturation (40), motility (41), morphology (42) and overall function $(43,44)$.

\section{Other food bioactive ingredients and male fertility}

\section{Gluten}

Celiac disease (CD) is an autoimmune-mediated enteropathy of the small intestine characterized by intolerance to dietary gluten in individuals with susceptible genotypes, human leukocyte antigens (HLA)-DQ2 and -DQ8, which are necessary but not sufficient for onset of disease (62). Ninety-nine percent of people with CD possess the DQ2 and DQ8 risk variants, which can be determined by 6 SNPs in the HLA gene region, compared with $30 \%$ of the general population $(179,180)$. Two immune pathways are involved in CD; one through deamidation of glutamine residues in gluten peptides by human transglutaminase 2 and generation of autoantibodies, and the other by activation of the innate immune system, leading to atrophy of intestinal villi (181). A viral infection model suggests that reovirus infections may trigger loss of oral tolerance of gluten (182). In addition, the microbiome plays pathogenic and protective roles through interactions that may modulate autoimmune risk in individuals with HLA-DQ2 (183).

$\mathrm{CD}$ is associated with extra-intestinal symptoms, such as infertility and decreased bone density $(63,184,185)$. Before treatment with a strict gluten-free diet, men may experience impaired pituitary regulation of gonadal endocrine function (186). The inflammatory response to gluten consumption in individuals with gluten intolerance creates an adverse environment for reproductive tissue maintenance and function (187). Available evidence does not show an increased risk of subfertility in men with CD, although auto-antibodies can be found in seminal fluid of men with unrecognized disease $(187,188)$.

Anti-sperm antibodies associated with the autoimmune response that $\mathrm{CD}$ incurs when gluten is consumed, as well as compromised nutritional status due to the disease, may be related to the pathogenesis of reduced sperm morphology and motility (64). The gut is a site of conversion of testosterone to dihydrotestosterone and influences hormone metabolism (189). In untreated celiac disease, low levels of testosterone and subsequent hormone imbalances can cause hypogonadism (63) and hypothalamic pituitary resistance, oligospermia, and azoospermia, disrupting reproductive function $(64,190)$. However, with the removal of gluten from the diet, semen parameters can increase and fertility can be restored (191). Further consequences of untreated $\mathrm{CD}$ in men include micronutrient deficiencies. These can include folate, vitamin A, vitamin $\mathrm{E}$, zinc, and selenium, all of which play an important role in maintaining reproductive health and protecting fertile tissues (192). Further research on this topic is warranted as more fortified, functional gluten-free foods come to the marketplace and these may reduce the risk of micronutrient deficiencies associated with a gluten-free diet $(193,194)$.

\section{Caffeine}

Studies linking caffeine consumption to various health outcomes remain inconsistent. This may be due, in part, to genetic differences in caffeine metabolism. The cytochrome P450 1A2 (CYP1A2) gene codes for the CYP1A2 enzyme, which is responsible for $95 \%$ of caffeine metabolism within the body $(65,195)$. Individuals with the CA or CC genotypes of rs762551 make up approximately $60 \%$ of the population (196), and are known to metabolize caffeine slower than those who have the AA genotype (65). Slower clearance of caffeine from the bloodstream in combination with high consumption is associated with increased risk of a number of adverse health outcomes, including heart $\operatorname{attack}(65)$.

In men, caffeine crosses the blood-testes barrier, and can be harbored in the gonadal tissues and excreted into the semen $(197,198)$. There is evidence to suggest that caffeine consumption is associated with increased incidence of aneuploidy, and other DNA damage in sperm cells (199). Though some studies have not found a positive or negative effect of this phenomenon on fertility $(67,200-203)$, others have reported dose-dependent effects of caffeine on sperm motility, number and morphology, such that consuming 1-2 cups of coffee per day had a positive effect on semen parameters, whereas consumption of zero or more than 2 cups per day was associated with diminished sperm motility and count, as well as poor morphology (66). However, higher intake of caffeine (>175 mg/day) has 
been positively associated with semen volume and circulating testosterone in men (67). There may be an inverse relationship between higher caffeine intake in men and lower fecundity $(204,205)$, but additional studies that include analysis of participant CYP1A2 genotype are needed.

\section{Macronutrients and male fertility}

\section{Fat}

Dietary fat has several important functions within the body. Its physiological roles include acting as an energy source, insulating organs and playing a crucial part in the creation of hormones, cell membranes and tissue membranes (206). However, diets high in fat can increase serum and semen triglyceride levels, which may increase oxidative stress in reproductive tissues (207), and have been linked to a higher risk of obesity $(208,209)$. Genetics play a role in dietary preference for fat. The cluster of differentiation 36 (CD36) gene impacts the transport of fat in the blood throughout the body, and overall perception of dietary fat. As such, "super tasters," or carriers of the GA or GG variants, can detect dietary fat at a heightened level in comparison to a "typical taster," or an individual with the AA variant of CD36 (210). It has been suggested that "super tasters" of fat may consume less dietary fat than "typical tasters" (211).

Transcription factor-7 like 2 (TCFL2) genotype controls the impact of dietary fat on body composition and several metabolic factors. Individuals who carry the TT genotype for rs7903146 comprise approximately $10 \%$ of the population. Those with the TT variant who consume a high proportion of dietary fat may be more likely to be overweight and experience insulin resistance compared to those with the CC or TC genotypes $(45,46)$. Both of these outcomes can have negative implications on fertility due to hormonal imbalances, oxidative stress causing sperm damage, and increased testicular temperature $(208,209,212,213)$.

In men, total dietary fat intake has been negatively associated with sperm count and concentration (47). Diets higher in fat can lead to hormonal disruption and a lack of testicular energy supply, compromising germ cells and mitochondria (214). Observed effects include disrupted sperm membranes, impaired motility and function, and decreased sperm quality (48). However, the most important factor when analyzing the relationship between dietary fat and fertility in men is the type of fat, as the ratio of unsaturated to saturated fat can influence semen quality $(47,48)$.

\section{Omega-3 fat}

Polyunsaturated omega-3 fat is a component of a healthy diet, found in fatty fish, nuts, seeds, and oils, and can help to maintain healthy levels of circulating triglycerides. The protein nitric oxide synthase (NOS) regulates the interaction between dietary fat and plasma triglycerides and is encoded by the nitric oxide synthase- 3 gene (NOS3). Variation in this gene changes how the NOS protein is expressed, and therefore different genotypes can affect circulating triglyceride levels in response to plasma omega-3 levels. In one study, individuals with the GT or TT genotype of NOS 3 had higher circulating triglycerides when plasma omega-3 fats were low, compared to those with the GG genotype (49). Circulating triglycerides have been shown to be positively correlated with sperm concentration, as well as having a concentration-dependent effect on sperm morphology (215).

Omega-3 and omega- 6 fatty acids are metabolized into long-chain polyunsaturated fatty acids (LC-PUFAs) that modulate blood pressure, blood clotting, and inflammation through the formation of eicosanoids (216). The production of LC-PUFAs is regulated by the fatty acid desaturase enzymes encoded by the FADS gene cluster. In particular, polymorphisms of the FADS1 and FADS2 genes are known to affect the rate of LC-PUFA synthesis (50). Polymorphisms in these genes influence the circulating levels of various metabolic forms of $n-3$ and n-6 fatty acids including eicosanoid precursors (217). Multiple studies have found that carriers of the $\mathrm{C}$ allele in the FADS1 gene (rs174547) had reduced endogenous production of LC-PUFAs $(51,52,218)$. SNPs in the FADS2 gene (rs2727270, rs498793) have also been correlated with altered PUFA metabolism $(51,52)$. The effects of these FADS polymorphisms on circulating lipid profiles and levels of eicosanoid precursors may affect male reproductive health through altering inflammatory responses and sperm membrane characteristics.

Omega-3 fats have been suggested to be the most important component in sperm membranes because of their contribution to sperm motility and membrane fluidity, as well as fertile potential of sperm $(53,54)$. Polyunsaturated fats in the sperm membrane are targets of lipid peroxidation, creating oxidative stress in the semen (219). Therefore, 
antioxidants such as vitamins $\mathrm{E}$ and $\mathrm{C}$ are necessary to protect unsaturated fats composing sperm and oocyte membranes, maintaining the integrity and function of these structures $(59,220)$. Lower ratios of omega- 6 to omega-3, and saturated to unsaturated fatty acids have been associated with better semen parameters, specifically sperm count, motility and morphology in oligoasthenoteratozoospermic men $(221,222)$.

In a 3-month trial of omega-3 fatty acid-based supplements from fish and algal oils for 10 men with asthenozoospermia, reduced concentrations of omega- 3 fatty acids in seminal plasma and sperm fatty acid profile were seen following supplementation, but no changes in seminal parameters were observed (223). In contrast, a randomized, double blind study of men undergoing evaluation for infertility who were given 1,500 $\mathrm{mg}$ per day of docosahexaenoic acid (DHA, a type of omega-3 fatty acid)-enriched oil over a 10-week period resulted in improvement in DHA and omega-3 fatty acid content in seminal plasma, and a reduction in the percentage of spermatozoa with DNA damage (224). Overall, the majority of studies suggest that increased intakes of omega-3 fatty acids are correlated with improved semen quality parameters (225). However, future research should focus on examining how NOS 3 and FADS1/2 genotypes directly modify these associations.

\section{Saturated fat}

Saturated fat has long been regarded as a marker of poor diet quality, due to its suggested link to diseases such as obesity (226). Apoprotein A-II (APOA2), a major protein of HDL, reduces the reverse efflux of cholesterol transport and its antioxidant function and is regulated by the $A P O A 2$ gene (55). Variation in the $A P O A 2$ (rs5082) gene is known to affect the way saturated fat intake impacts body mass index (BMI), such that carriers of the CC genotype had a stronger correlation between saturated fat intake and BMI than those with the TC or TT genotypes (55). Individuals with a higher BMI score and the CC genotype have been observed to have higher saturated fat intakes than lowerweight carriers of the $\mathrm{T}$ allele of the $A P O A 2$ gene (55), which can impact circulating fatty acids (226) and the composition and quality of reproductive tissues in men $(47,227)$. Further, higher BMI is a risk factor for infertility (209,212). Therefore, carriers of the APOA2 CC genotype may benefit from a limited intake of saturated fats.

Dietary saturated fat has been shown to negatively affect sperm count and concentration $(47,228,229)$, as well as poor sperm motility $(229,230)$ and morphology $(231,232)$. Saturated fat content in sperm membranes has been shown to be higher in infertile men, specifically with asthenozoospermia and oligozoospermia when compared to normozoospermic men $(56,57)$. Sperm membrane composition is integral to fluidity and function, as well as sperm motility, viability and susceptibility to lipid peroxidation (233-235), which are compromised in infertile men $(56,236)$.

\section{Sugar}

The 2015-2020 Dietary Guidelines for Americans recommend an intake of no more than $10 \%$ of calories from added sugars (237). The glucose transporter type-2 (GLUT2) protein influences glucose levels in the body and variation in the GLUT2 (rs5400) gene dictates its production. Carriers of the $\mathrm{T}$ allele have been shown to have a lower sensitivity and thus higher preference for glucose when compared to carriers of the CC genotype (58). Sugar intake can be an important factor contributing to daily caloric intake, and in excess can drive the development of chronic diseases such as obesity and type 2 diabetes (238), which can have negative implications on fertility (239-242). The existing literature focuses on one concentrated source of added sugar: sugar-sweetened beverages (SSBs).

Higher sugar-sweetened beverage consumption has been associated with lower sperm motility and sperm count, after adjustment for caffeine and BMI (243). Male mice fed an SSB analog had reduced fertility rates by $25 \%$ in comparison to controls not provided an SSB analog (244). In a large cohort of Asian men, higher intake of sweet snacks and SSBs was associated with lower sperm count (245). Additionally, a prospective cohort study of 2,554 Danish men found that self-reported consumption of SSBs negatively correlated with sperm count, concentration, and morphology. However, the study's results may have also been influenced by poorer lifestyle factors among the high SSB-consuming individuals, including higher self-reported consumption of red meats and alcohol (59). Other health effects of excess sugar consumption in men include insulin resistance, oxidative stress, and an altered hormone profile, all of which are linked to poor semen parameters and infertility $(213,246)$. However, some studies have found no association between SSB intake and semen parameters $(67,247)$. 


\section{Fiber}

Whole grain wheat is a rich source of methionine, betaine, choline and folate, all of which are involved in the methylation of DNA. Whole grains also provide dietary fiber, which can mitigate rapid increases in blood glucose following ingestion of carbohydrates. Diets rich in fiber are known to be inversely associated with insulin resistance and incidence of type 2 diabetes $(248,249)$. The transcription factor-7 like-2 (TCF7L2) protein plays a role in the development of type 2 diabetes by impacting insulin secretion and hepatic glucose production, and is encoded by the TCF7L2 gene (60). Possession of the $\mathrm{T}$ allele of the TCF7L2 (rs12255372) gene is associated greater expression of the TCF7L2 protein, impaired insulin sensitivity, and thus a higher risk of developing type 2 diabetes, which can have detrimental effects on male fertility (250). As an endocrine disorder, type 2 diabetes can alter a man's hormone profile such that spermatogenesis, steroidogenesis, sperm maturation, and ejaculation are negatively impacted (61). Glucose transporter function and therefore the bioavailability of glucose are integral to processes such as sperm production, maturation, and fertilization $(236,251)$. The presence of type 2 diabetes may compromise sperm motility, DNA integrity and seminal composition $(251,252)$, negatively impacting overall fertility (241). Sperm DNA damage may be attributable to diabetes-induced oxidative stress and lipid peroxidation (253), which can result in poor implantation, embryonic development, and low clinical pregnancy rate (252).

Research has shown that a diet rich in whole grains promotes better sperm morphology and motility $(26,254)$. High fiber diets can play an important role in supporting greater fecal microbiome diversity, but little evidence exists on the direct influence of diet on the reproductive microbiome. It is known that host genetics and diet influence the development of the microbiome $(255,256)$. Also, obesity, insulin resistance, inflammation and dyslipidemia occur less frequently in individuals with greater microbiome diversity (257). There is a need for research exploring the interaction between diet, reproductive health and the microbiome (258).

\section{Conclusion and future directions}

Overall, evidence to date suggests that nutritional status plays an important role in male fertility, and common genetic variations influence nutrient metabolism and response to dietary intake. The interaction between nutrition, male fertility and genetic variation remains little explored, but there is evidence that these three factors are interrelated and should be examined together in scientific literature and clinical practice to increase our understanding of reproductive function and enhance fertility outcomes. Men experiencing infertility may seek support from registered dietitians to ensure dietary intakes meet requirements for essential nutrients. Future research may provide clarity by focusing on tailoring dietary recommendations to individuals based on genetic susceptibilities to deficiencies and toxicities.

\section{Acknowledgments}

Funding: The authors acknowledge and thank the Allen Foundation Inc. (grant number 505239) and Nutrigenomix Inc. (grant number 1005) for funding support.

\section{Footnote}

Provenance and Peer Review: This article was commissioned by the Guest Editors (Keith Jarvi and Jared Bieniek) for the series "Genetic Causes and Management of Male Infertility" published in Translational Andrology and Urology. The article was sent for external peer review organized by the Guest Editors and the editorial office.

Conflicts of Interest: All authors have completed the ICMJE uniform disclosure form (available at http://dx.doi. org/10.21037/tau-20-592). The series "Genetic Causes and Management of Male Infertility" was commissioned by the editorial office without any funding or sponsorship. $\mathrm{KJ}$ served as the unpaid Guest Editor of the series. SMV is the Manager of Research and Education at Nutrigenomix Inc, which is a company that provides genetic testing for personalized nutrition. BGB is the Director of Research and Development at Nutrigenomix Inc, a company that develops genetic testing kits for personalized nutrition. AES reports grants from Allen Foundation, personal fees from Nutrigenomix Inc., during the conduct of the study; personal fees from Nutrigenomix Inc., outside the submitted work; AES is the founder and hold shares in Nutrigenomix Inc, which is a company that provides genetic testing for personalized nutrition. The authors have no other conflicts of interest to declare.

Ethical Statement: The authors are accountable for all 
aspects of the work in ensuring that questions related to the accuracy or integrity of any part of the work are appropriately investigated and resolved.

Open Access Statement: This is an Open Access article distributed in accordance with the Creative Commons Attribution-NonCommercial-NoDerivs 4.0 International License (CC BY-NC-ND 4.0), which permits the noncommercial replication and distribution of the article with the strict proviso that no changes or edits are made and the original work is properly cited (including links to both the formal publication through the relevant DOI and the license). See: https://creativecommons.org/licenses/by-nc-nd/4.0/.

\section{References}

1. Zegers-Hochschild F, Adamson GD, Dyer S, et al. The International Glossary on Infertility and Fertility Care, 2017. Hum Reprod 2017;32:1786-801.

2. Practice Committee of American Society for Reproductive Medicine. Diagnostic evaluation of the infertile male: a committee opinion. Fertil Steril 2012;98:294-301.

3. Agarwal A, Virk G, Ong C, et al. Effect of oxidative stress on male reproduction. World J Mens Health 2014;32:1-17.

4. Canada; Go. Fertility 2013 [updated Feb 4 2013. Available online: http://healthycanadians.gc.ca/healthy-living-viesaine/pregnancy-grossesse/fertility-fertilite/fert-eng.php

5. Mascarenhas MN, Flaxman SR, Boerma T, et al. National, regional, and global trends in infertility prevalence since 1990: a systematic analysis of 277 health surveys. PLoS Med 2012;9:e1001356.

6. Bushnik T, Cook JL, Yuzpe AA, et al. Estimating the prevalence of infertility in Canada. Hum Reprod 2012;27:738-46.

7. Agarwal A, Mulgund A, Hamada A, et al. A unique view on male infertility around the globe. Reprod Biol Endocrinol 2015;13:37.

8. Buhling KJ, Grajecki D. The effect of micronutrient supplements on female fertility. Curr Opin Obstet Gynecol 2013;25:173-80.

9. Buhling KJ, Laakmann E. The effect of micronutrient supplements on male fertility. Curr Opin Obstet Gynecol 2014;26:199-209.

10. Gaskins AJ, Chavarro JE. Diet and fertility: a review. Am J Obstet Gynecol 2018;218:379-89.

11. Lietz G, Oxley A, Leung W, et al. Single nucleotide polymorphisms upstream from the beta-carotene $15,15^{\prime}$-monoxygenase gene influence provitamin A conversion efficiency in female volunteers. J Nutr 2012;142:161S-5S.

12. Chihara M, Otsuka S, Ichii O, et al. Vitamin A deprivation affects the progression of the spermatogenic wave and initial formation of the blood-testis barrier, resulting in irreversible testicular degeneration in mice. J Reprod Dev 2013;59:525-35.

13. Li N, Mruk DD, Cheng CY. Actin binding proteins in blood-testis barrier function. Curr Opin Endocrinol Diabetes Obes 2015;22:238-47.

14. Tanwar VS, Chand MP, Kumar J, et al. Common variant in FUT2 gene is associated with levels of vitamin $\mathrm{B}(12)$ in Indian population. Gene 2013;515:224-8.

15. Banihani SA. Vitamin B12 and Semen Quality. Biomolecules 2017;7:42.

16. Cahill LE, Fontaine-Bisson B, El-Sohemy A. Functional genetic variants of glutathione $\mathrm{S}$-transferase protect against serum ascorbic acid deficiency. Am J Clin Nutr 2009; $90: 1411-7$.

17. Thiele JJ, Friesleben HJ, Fuchs J, et al. Ascorbic acid and urate in human seminal plasma: determination and interrelationships with chemiluminescence in washed semen. Hum Reprod 1995;10:110-5.

18. Slater NA, Rager ML, Havrda DE, et al. Genetic Variation in CYP2R1 and GC Genes Associated With Vitamin D Deficiency Status. J Pharm Pract 2017;30:31-6.

19. Wang TJ, Zhang F, Richards JB, et al. Common genetic determinants of vitamin D insufficiency: a genome-wide association study. Lancet 2010;376:180-8.

20. Blomberg Jensen M, Bjerrum PJ, Jessen TE, et al. Vitamin $\mathrm{D}$ is positively associated with sperm motility and increases intracellular calcium in human spermatozoa. Hum Reprod 2011;26:1307-17.

21. Blomberg Jensen M, Lawaetz JG, Petersen JH, et al. Effects of Vitamin D Supplementation on Semen Quality, Reproductive Hormones, and Live Birth Rate: A Randomized Clinical Trial. J Clin Endocrinol Metab 2018;103:870-81.

22. Borel P, Desmarchelier C. Genetic Variations Involved in Vitamin E Status. Int J Mol Sci 2016;17:2094.

23. Geva E, Bartoov B, Zabludovsky N, et al. The effect of antioxidant treatment on human spermatozoa and fertilization rate in an in vitro fertilization program. Fertil Steril 1996;66:430-4.

24. Suleiman SA, Ali ME, Zaki ZM, et al. Lipid peroxidation and human sperm motility: protective role of vitamin E. J Androl 1996;17:530-7.

25. Stern LL, Mason JB, Selhub J, et al. Genomic DNA 
hypomethylation, a characteristic of most cancers, is present in peripheral leukocytes of individuals who are homozygous for the C677T polymorphism in the methylenetetrahydrofolate reductase gene. Cancer Epidemiol Biomarkers Prev 2000;9:849-53.

26. Mendiola J, Torres-Cantero AM, Vioque J, et al. A low intake of antioxidant nutrients is associated with poor semen quality in patients attending fertility clinics. Fertil Steril 2010;93:1128-33.

27. Johnson AR, Lao S, Wang T, et al. Choline dehydrogenase polymorphism rs12676 is a functional variation and is associated with changes in human sperm cell function. PLoS One. 2012;7:e36047.

28. Zeisel SH. Gene response elements, genetic polymorphisms and epigenetics influence the human dietary requirement for choline. IUBMB Life 2007;59:380-7.

29. Ganz AB, Cohen VV, Swersky CC, et al. Genetic Variation in Choline-Metabolizing Enzymes Alters Choline Metabolism in Young Women Consuming Choline Intakes Meeting Current Recommendations. Int J Mol Sci 2017;18:252.

30. da Costa KA, Kozyreva OG, Song J, et al. Common genetic polymorphisms affect the human requirement for the nutrient choline. FASEB J 2006;20:1336-44.

31. Kelly TL, Neaga OR, Schwahn BC, et al. Infertility in 5,10-methylenetetrahydrofolate reductase (MTHFR)deficient male mice is partially alleviated by lifetime dietary betaine supplementation. Biol Reprod 2005;72:667-77.

32. Benyamin B, Ferreira MA, Willemsen G, et al. Common variants in TMPRSS6 are associated with iron status and erythrocyte volume. Nat Genet 2009;41:1173-5.

33. Pichler I, Minelli C, Sanna S, et al. Identification of a common variant in the TFR2 gene implicated in the physiological regulation of serum iron levels. Hum Mol Genet 2011;20:1232-40.

34. Benyamin B, McRae AF, Zhu G, et al. Variants in TF and $\mathrm{HFE}$ explain approximately $40 \%$ of genetic variation in serum-transferrin levels. Am J Hum Genet 2009;84:60-5.

35. Ganesh SK, Zakai NA, van Rooij FJ, et al. Multiple loci influence erythrocyte phenotypes in the CHARGE Consortium. Nat Genet 2009;41:1191-8.

36. Trrda E, Peer R, Sikka SC, et al. Iron and copper in male reproduction: a double-edged sword. J Assist Reprod Genet 2015;32:3-16.

37. Agbaraji VO, Scott RB, Leto S, et al. Fertility studies in sickle cell disease: semen analysis in adult male patients. Int J Fertil 1988;33:347-52.
38. Wellejus A, Poulsen HE, Loft S. Iron-induced oxidative DNA damage in rat sperm cells in vivo and in vitro. Free Radic Res 2000;32:75-83.

39. Fang Y, van Meurs JB, Arp P, et al. Vitamin D binding protein genotype and osteoporosis. Calcif Tissue Int 2009;85:85-93.

40. Blomberg Jensen M, Nielsen JE, Jorgensen A, et al. Vitamin D receptor and vitamin D metabolizing enzymes are expressed in the human male reproductive tract. Hum Reprod 2010;25:1303-11.

41. Prien SD, Lox CD, Messer RH, et al. Seminal concentssrations of total and ionized calcium from men with normal and decreased motility. Fertil Steril 1990;54:171-2.

42. Adamopoulos DA, Deliyiannis V. Seminal plasma magnesium, calcium and inorganic phosphate concentration in normozoospermic and subfertile men. Andrologia 1983;15:648-54.

43. Wong WY, Flik G, Groenen PM, et al. The impact of calcium, magnesium, zinc, and copper in blood and seminal plasma on semen parameters in men. Reprod Toxicol 2001;15:131-6.

44. Hong CY, Chiang BN, Turner P. Calcium ion is the key regulator of human sperm function. Lancet 1984;2:1449-51.

45. Grau K, Cauchi S, Holst C, et al. TCF7L2 rs7903146macronutrient interaction in obese individuals' responses to a 10-wk randomized hypoenergetic diet. Am J Clin Nutr 2010;91:472-9.

46. Mattei J, Qi Q, Hu FB, et al. TCF7L2 genetic variants modulate the effect of dietary fat intake on changes in body composition during a weight-loss intervention. Am J Clin Nutr 2012;96:1129-36.

47. Attaman JA, Toth TL, Furtado J, et al. Dietary fat and semen quality among men attending a fertility clinic. Hum Reprod 2012;27:1466-74.

48. Rato L, Alves MG, Cavaco JE, et al. High-energy diets: a threat for male fertility? Obes Rev 2014;15:996-1007.

49. Ferguson JF, Phillips CM, McMonagle J, et al. NOS3 gene polymorphisms are associated with risk markers of cardiovascular disease, and interact with omega-3 polyunsaturated fatty acids. Atherosclerosis 2010;211:539-44.

50. Lattka E, Illig T, Koletzko B, et al. Genetic variants of the FADS1 FADS2 gene cluster as related to essential fatty acid metabolism. Curr Opin Lipidol 2010;21:64-9.

51. Merino DM, Johnston H, Clarke S, et al. Polymorphisms in FADS1 and FADS2 alter desaturase activity in 
young Caucasian and Asian adults. Mol Genet Metab 2011;103:171-8.

52. Huang MC, Chang WT, Chang HY, et al. FADS Gene Polymorphisms, Fatty Acid Desaturase Activities, and HDL-C in Type 2 Diabetes. Int J Environ Res Public Health 2017;14:572.

53. Esmaeili V, Shahverdi AH, Moghadasian MH, et al. Dietary fatty acids affect semen quality: a review. Andrology 2015;3:450-61.

54. Roqueta-Rivera M, Abbott TL, Sivaguru M, et al. Deficiency in the omega-3 fatty acid pathway results in failure of acrosome biogenesis in mice. Biol Reprod 2011;85:721-32.

55. Corella D, Peloso G, Arnett DK, et al. APOA2, dietary fat, and body mass index: replication of a gene-diet interaction in 3 independent populations. Arch Intern Med 2009;169:1897-906.

56. Aksoy Y, Aksoy H, Altinkaynak K, et al. Sperm fatty acid composition in subfertile men. Prostaglandins Leukot Essent Fatty Acids 2006;75:75-9.

57. Conquer JA, Martin JB, Tummon I, et al. Fatty acid analysis of blood serum, seminal plasma, and spermatozoa of normozoospermic vs. asthenozoospermic males. Lipids 1999;34:793-9.

58. Eny KM, Wolever TM, Fontaine-Bisson B, et al. Genetic variant in the glucose transporter type 2 is associated with higher intakes of sugars in two distinct populations. Physiol Genomics 2008;33:355-60.

59. Mehendale SS, Kilari Bams AS, Deshmukh CS, et al. Oxidative stress-mediated essential polyunsaturated fatty acid alterations in female infertility. Hum Fertil (Camb) 2009; 12:28-33.

60. Lyssenko V, Lupi R, Marchetti P, et al. Mechanisms by which common variants in the TCF7L2 gene increase risk of type 2 diabetes. J Clin Invest 2007;117:2155-63.

61. Jangir RN, Jain GC. Diabetes mellitus induced impairment of male reproductive functions: a review. Curr Diabetes Rev 2014;10:147-57.

62. Verdu EF, Caminero A. How infection can incite sensitivity to food. Science 2017;356:29-30.

63. Walker MD, Zylberberg HM, Green PHR, et al. Endocrine complications of celiac disease: a case report and review of the literature. Endocr Res 2019;44:27-45.

64. Farthing MJ, Edwards CR, Rees LH, et al. Male gonadal function in coeliac disease: 1 . Sexual dysfunction, infertility, and semen quality. Gut 1982;23:608-14.

65. Cornelis MC, El-Sohemy A, Kabagambe EK, et al. Coffee, CYP1A2 genotype, and risk of myocardial infarction.
JAMA 2006;295:1135-41.

66. Dlugosz L, Bracken MB. Reproductive effects of caffeine: a review and theoretical analysis. Epidemiol Rev 1992;14:83-100.

67. Ramlau-Hansen CH, Thulstrup AM, Bonde JP, et al. Semen quality according to prenatal coffee and present caffeine exposure: two decades of follow-up of a pregnancy cohort. Hum Reprod 2008;23:2799-805.

68. Omu AE, Fatinikun T, Mannazhath N, et al. Significance of simultaneous determination of serum and seminal plasma alpha-tocopherol and retinol in infertile men by high-performance liquid chromatography. Andrologia 1999;31:347-54.

69. Palan P, Naz R. Changes in various antioxidant levels in human seminal plasma related to immunoinfertility. Arch Androl 1996;36:139-43.

70. Al-Azemi MK, Omu AE, Fatinikun T, et al. Factors contributing to gender differences in serum retinol and alpha-tocopherol in infertile couples. Reprod Biomed Online 2009;19:583-90.

71. Clagett-Dame M, Knutson D. Vitamin A in reproduction and development. Nutrients 2011;3:385-428.

72. Yokota S, Shirahata T, Yusa J, et al. Long-term dietary intake of excessive vitamin A impairs spermatogenesis in mice. J Toxicol Sci 2019;44:257-71.

73. Ensembl. rs11645428 2020. Available online: http:// useast.ensembl.org/Homo_sapiens/Variation/ Population? $\mathrm{r}=16: 81224791-81225791$; source=dbSNP; $=\mathrm{rs}$ $11645428 ; \mathrm{vdb}=$ variation; $\mathrm{vf}=24401000$

74. Koubova J, Hu YC, Bhattacharyya T, et al. Retinoic acid activates two pathways required for meiosis in mice. PLoS Genet 2014;10:e1004541.

75. Forges T, Monnier-Barbarino P, Alberto JM, et al. Impact of folate and homocysteine metabolism on human reproductive health. Hum Reprod Update 2007;13:225-38.

76. Tyagi N, Sedoris KC, Steed M, et al. Mechanisms of homocysteine-induced oxidative stress. Am J Physiol Heart Circ Physiol 2005;289:H2649-56.

77. Sadeghian S, Fallahi F, Salarifar M, et al. Homocysteine, vitamin $\mathrm{B} 12$ and folate levels in premature coronary artery disease. BMC Cardiovasc Disord 2006;6:38.

78. Boxmeer JC, Smit M, Utomo E, et al. Low folate in seminal plasma is associated with increased sperm DNA damage. Fertil Steril 2009;92:548-56.

79. Vujkovic M, de Vries JH, Dohle GR, et al. Associations between dietary patterns and semen quality in men undergoing IVF/ICSI treatment. Hum Reprod 2009;24:1304-12. 
80. Safarinejad MR, Shafiei N, Safarinejad S. Relationship between genetic polymorphisms of methylenetetrahydrofolate reductase (C677T, A1298C, and G1793A) as risk factors for idiopathic male infertility. Reprod Sci 2011;18:304-15.

81. Fang H, Kang J, Zhang D. Microbial production of vitamin B12: a review and future perspectives. Microb Cell Fact 2017;16:15.

82. Ensembl. rs602662 2020. Available online: http:// useast.ensembl.org/Homo_sapiens/Variation/ Population? $\mathrm{db}=$ core; $r=19: 48703228-48704228 ; \mathrm{v}=\mathrm{rs} 602662$ ;vdb=variation; $\mathrm{vf}=45190782$

83. Dhillon VS, Shahid M, Husain SA. Associations of MTHFR DNMT3b 4977 bp deletion in mtDNA and GSTM1 deletion, and aberrant $\mathrm{CpG}$ island hypermethylation of GSTM1 in non-obstructive infertility in Indian men. Mol Hum Reprod 2007;13:213-22.

84. Murphy LE, Mills JL, Molloy AM, et al. Folate and vitamin B12 in idiopathic male infertility. Asian J Androl 2011;13:856-61.

85. Kralikova M, Crha I, Huser M, et al. The intracellular concentration of homocysteine and related thiols is negatively correlated to sperm quality after highly effective method of sperm lysis. Andrologia 2017;49.

86. Luck MR, Jeyaseelan I, Scholes RA. Ascorbic acid and fertility. Biol Reprod 1995;52:262-6.

87. Ensembl. GSTT1 2020. Available online: http://useast. ensembl.org/Homo_sapiens/Gene/Summary? $\mathrm{db}=\mathrm{c}$ ore;g=ENSG00000277656;r=CHR_HSCHR22_1_ CTG7:24033952-24042493

88. Yuan L, Zhang L, Ma W, et al. Glutathione S-transferase M1 and T1 gene polymorphisms with consumption of high fruit-juice and vegetable diet affect antioxidant capacity in healthy adults. Nutrition 2013;29:965-71.

89. Agarwal A, Sekhon LH. The role of antioxidant therapy in the treatment of male infertility. Hum Fertil (Camb) 2010;13:217-25.

90. Fraga CG, Motchnik PA, Shigenaga MK, et al. Ascorbic acid protects against endogenous oxidative DNA damage in human sperm. Proc Natl Acad Sci U S A 1991;88:11003-6.

91. Lewis SE, Sterling ES, Young IS, et al. Comparison of individual antioxidants of sperm and seminal plasma in fertile and infertile men. Fertil Steril 1997;67:142-7.

92. Silver EW, Eskenazi B, Evenson DP, et al. Effect of antioxidant intake on sperm chromatin stability in healthy nonsmoking men. J Androl 2005;26:550-6.

93. Young SS, Eskenazi B, Marchetti FM, et al. The association of folate, zinc and antioxidant intake with sperm aneuploidy in healthy non-smoking men. Hum Reprod 2008;23:1014-22.

94. Rolf C, Cooper TG, Yeung CH, et al. Antioxidant treatment of patients with asthenozoospermia or moderate oligoasthenozoospermia with high-dose vitamin $\mathrm{C}$ and vitamin E: a randomized, placebo-controlled, double-blind study. Hum Reprod 1999;14:1028-33.

95. Salas-Huetos A, Bullo M, Salas-Salvado J. Dietary patterns, foods and nutrients in male fertility parameters and fecundability: a systematic review of observational studies. Hum Reprod Update 2017;23:371-89.

96. Rahimlou M, Sohaei S, Nasr-Esfahani M, et al. Dietary Antioxidant Intake in Relation to Semen Quality Parameters in Infertile Men: a Cross-Sectional Study. Clin Nutr Res 2019;8:229-37.

97. Greco E, Iacobelli M, Rienzi L, et al. Reduction of the incidence of sperm DNA fragmentation by oral antioxidant treatment. J Androl 2005;26:349-53.

98. Schmid TE, Eskenazi B, Marchetti F, et al. Micronutrients intake is associated with improved sperm DNA quality in older men. Fertil Steril 2012;98:1130-7.e1.

99. Song GJ, Norkus EP, Lewis V. Relationship between seminal ascorbic acid and sperm DNA integrity in infertile men. Int J Androl 2006;29:569-75.

100. Du J, Cullen JJ, Buettner GR. Ascorbic acid: chemistry, biology and the treatment of cancer. Biochim Biophys Acta 2012;1826:443-57.

101.Agarwal A, Nallella KP, Allamaneni SS, et al. Role of antioxidants in treatment of male infertility: an overview of the literature. Reprod Biomed Online 2004;8:616-27.

102. Ozkan S, Jindal S, Greenseid K, et al. Replete vitamin $\mathrm{D}$ stores predict reproductive success following in vitro fertilization. Fertil Steril 2010;94:1314-9.

103. Institute of Medicine FaNB. Dietary Reference Intakes for Calcium and Vitamin D. Washington, DC: National Academy Press; 2010.

104. Holick MF. Vitamin D: importance in the prevention of cancers, type 1 diabetes, heart disease, and osteoporosis. Am J Clin Nutr 2004;79:362-71.

105. Holick MF. Skin: site of the synthesis of vitamin D and a target tissue for the active form, 1,25-dihydroxyvitamin D3. Ann N Y Acad Sci 1988;548:14-26.

106.Ensembl. rs2282679 2020. Available online: http:// useast.ensembl.org/Homo_sapiens/Variation/ Explore? $\mathrm{r}=4$ :71742166-71743166; $=\mathrm{rs} 2282679 ; \mathrm{vdb}=$ variati on;vf $=65629865$

107.Ensembl. rs10741657 2020. Available online: http:// 
useast.ensembl.org/Homo_sapiens/Variation/

Explore?r=11:14892832-14893832;v=rs10741657;vdb=vari ation;vf $=85747174$

108. Bikle DD. Vitamin D metabolism and function in the skin. Mol Cell Endocrinol 2011;347:80-9.

109. Blomberg Jensen M, Jorgensen A, Nielsen JE, et al. Expression of the vitamin D metabolizing enzyme CYP24A1 at the annulus of human spermatozoa may serve as a novel marker of semen quality. Int $\mathrm{J}$ Androl 2012;35:499-510.

110.Anagnostis P, Karras S, Goulis DG. Vitamin D in human reproduction: a narrative review. Int $\mathrm{J}$ Clin Pract 2013;67:225-35.

111.Johnson JA, Grande JP, Roche PC, et al. Immunohistochemical detection and distribution of the 1,25-dihydroxyvitamin D3 receptor in rat reproductive tissues. Histochem Cell Biol 1996;105:7-15.

112.Aquila S, Guido C, Middea E, et al. Human male gamete endocrinology: 1alpha, 25-dihydroxyvitamin D3 $(1,25(\mathrm{OH}) 2 \mathrm{D} 3)$ regulates different aspects of human sperm biology and metabolism. Reprod Biol Endocrinol 2009;7:140.

113. Foresta C, Strapazzon G, De Toni L, et al. Bone mineral density and testicular failure: evidence for a role of vitamin D 25-hydroxylase in human testis. J Clin Endocrinol Metab 2011;96:E646-52.

114.Pludowski P, Holick MF, Pilz S, et al. Vitamin D effects on musculoskeletal health, immunity, autoimmunity, cardiovascular disease, cancer, fertility, pregnancy, dementia and mortality-a review of recent evidence. Autoimmun Rev 2013;12:976-89.

115. Nimptsch K, Platz EA, Willett WC, et al. Association between plasma 25-OH vitamin $\mathrm{D}$ and testosterone levels in men. Clin Endocrinol (Oxf) 2012;77:106-12.

116. Pilz S, Frisch S, Koertke H, et al. Effect of vitamin D supplementation on testosterone levels in men. Horm Metab Res 2011;43:223-5.

117. Yang B, Sun H, Wan Y, et al. Associations between testosterone, bone mineral density, vitamin $\mathrm{D}$ and semen quality in fertile and infertile Chinese men. Int J Androl 2012;35:783-92.

118. Karras S, Anagnostis P, Kotsa K, et al. Vitamin D and gonadal function in men: a potential inverse U-shaped association? Andrology 2016;4:542-4.

119.Deng XL, Li YM, Yang XY, et al. Efficacy and safety of vitamin $\mathrm{D}$ in the treatment of idiopathic oligoasthenozoospermia. Zhonghua Nan Ke Xue 2014;20:1082-5.
120. Blomberg Jensen M, Gerner Lawaetz J, Andersson AM, et al. Vitamin D deficiency and low ionized calcium are linked with semen quality and sex steroid levels in infertile men. Hum Reprod 2016;31:1875-85.

121. National Institutes of Health. Vitamin D 2011. updated June 24, 2011.

122.Zhu CL, Xu QF, Li SX, et al. Investigation of serum vitamin D levels in Chinese infertile men. Andrologia 2016;48:1261-6.

123. Johnson CH, Slanar O, Krausz KW, et al. Novel metabolites and roles for alpha-tocopherol in humans and mice discovered by mass spectrometry-based metabolomics. Am J Clin Nutr 2012;96:818-30.

124. Schmölz L, Birringer M, Lorkowski S, et al. Complexity of vitamin E metabolism. World J Biol Chem 2016;7:14-43.

125. Sanocka D, Kurpisz M. Reactive oxygen species and sperm cells. Reprod Biol Endocrinol 2004;2:12.

126. Keskes-Ammar L, Feki-Chakroun N, Rebai T, et al. Sperm oxidative stress and the effect of an oral vitamin $\mathrm{E}$ and selenium supplement on semen quality in infertile men. Arch Androl 2003;49:83-94.

127. Vézina D, Mauffette F, Roberts KD, et al. Seleniumvitamin E supplementation in infertile men. Effects on semen parameters and micronutrient levels and distribution. Biol Trace Elem Res 1996;53:65-83.

128. Benedetti S, Tagliamonte MC, Catalani S, et al. Differences in blood and semen oxidative status in fertile and infertile men, and their relationship with sperm quality. Reprod Biomed Online 2012;25:300-6.

129. Czeizel AE, Dudas I. Prevention of the first occurrence of neural-tube defects by periconceptional vitamin supplementation. N Engl J Med 1992;327:1832-5.

130. Boxmeer JC, Brouns RM, Lindemans J, et al. Preconception folic acid treatment affects the microenvironment of the maturing oocyte in humans. Fertil Steril 2008;89:1766-70.

131. Ebisch IM, Thomas CM, Peters WH, et al. The importance of folate, zinc and antioxidants in the pathogenesis and prevention of subfertility. Hum Reprod Update 2007;13:163-74.

132.Ensembl. rs1801133 2020. Available online: https:// useast.ensembl.org/Homo_sapiens/Variation/ Population? $\mathrm{r}=1: 11795821-11796821 ; \mathrm{v}=\mathrm{rs} 1801133 ; \mathrm{vdb}=\mathrm{var}$ iation; $\mathrm{vf}=1165994$

133. Chen Q, Ng V, Mei J, et al. Comparison of seminal vitamin B12, folate, reactive oxygen species and various sperm parameters between fertile and infertile males. Wei Sheng Yan Jiu 2001;30:80-2. 
134. Ebisch IM, van Heerde WL, Thomas CM, et al. C677T methylenetetrahydrofolate reductase polymorphism interferes with the effects of folic acid and zinc sulfate on sperm concentration. Fertil Steril 2003;80:1190-4.

135. Eskenazi B, Kidd SA, Marks AR, et al. Antioxidant intake is associated with semen quality in healthy men. Hum Reprod 2005;20:1006-12.

136. Wong WY, Merkus HM, Thomas CM, et al. Effects of folic acid and zinc sulfate on male factor subfertility: a double-blind, randomized, placebo-controlled trial. Fertil Steril 2002;77:491-8.

137. Crha I, Kralikova M, Melounova J, et al. Seminal plasma homocysteine, folate and cobalamin in men with obstructive and non-obstructive azoospermia. J Assist Reprod Genet 2010;27:533-8.

138. Azizollahi G, Azizollahi S, Babaei H, et al. Effects of supplement therapy on sperm parameters, protamine content and acrosomal integrity of varicocelectomized subjects. J Assist Reprod Genet 2013;30:593-9.

139. Bentivoglio G, Melica F, Cristoforoni P. Folinic acid in the treatment of human male infertility. Fertil Steril 1993;60:698-701.

140.Mfady DS, Sadiq MF, Khabour OF, et al. Associations of variants in MTHFR and MTRR genes with male infertility in the Jordanian population. Gene 2014;536:40-4.

141. Gupta N, Gupta S, Dama M, et al. Strong association of $677 \mathrm{C}>\mathrm{T}$ substitution in the MTHFR gene with male infertility--a study on an indian population and a metaanalysis. PLoS One 2011;6:e22277.

142.Lee HC, Jeong YM, Lee SH, et al. Association study of four polymorphisms in three folate-related enzyme genes with non-obstructive male infertility. Hum Reprod 2006;21:3162-70.

143. Gava MM, Kayaki EA, Bianco B, et al. Polymorphisms in folate-related enzyme genes in idiopathic infertile Brazilian men. Reprod Sci 2011;18:1267-72.

144. Govindaiah V, Naushad SM, Prabhakara K, et al. Association of parental hyperhomocysteinemia and C677T Methylene tetrahydrofolate reductase (MTHFR) polymorphism with recurrent pregnancy loss. Clin Biochem 2009;42:380-6.

145. Clément A, Menezo Y, Cohen M, et al. 5-Methyltetrahydrofolate reduces blood homocysteine level significantly in C677T methyltetrahydrofolate reductase single-nucleotide polymorphism carriers consulting for infertility. J Gynecol Obstet Hum Reprod 2020;49:101622.

146.Zeisel SH. The fetal origins of memory: the role of dietary choline in optimal brain development. J Pediatr 2006;149:S131-6.

147. Wiedeman AM, Barr SI, Green TJ, et al. Dietary Choline Intake: Current State of Knowledge Across the Life Cycle. Nutrients 2018;10:1513.

148. Dietary Reference Intakes for Thiamin, Riboflavin, Niacin, Vitamin B6, Folate, Vitamin B12, Pantothenic Acid, Biotin, and Choline. The National Academies Collection: Reports funded by National Institutes of Health. Washington (DC), 1998.

149. Ducker GS, Rabinowitz JD. One-Carbon Metabolism in Health and Disease. Cell Metab 2017;25:27-42.

150. Friso S, Udali S, De Santis D, et al. One-carbon metabolism and epigenetics. Mol Aspects Med 2017;54:28-36.

151. Ganz AB, Shields K, Fomin VG, et al. Genetic impairments in folate enzymes increase dependence on dietary choline for phosphatidylcholine production at the expense of betaine synthesis. FASEB J 2016;30:3321-33.

152. Craig SA. Betaine in human nutrition. Am J Clin Nutr 2004;80:539-49.

153. Shadmehr S, Fatemi Tabatabaei SR, Hosseinifar S, et al. Attenuation of heat stress-induced spermatogenesis complications by betaine in mice. Theriogenology 2018;106:117-26.

154. Obeid R. The metabolic burden of methyl donor deficiency with focus on the betaine homocysteine methyltransferase pathway. Nutrients 2013;5:3481-95.

155.Dattilo M, Giuseppe D, Ettore C, et al. Improvement of gamete quality by stimulating and feeding the endogenous antioxidant system: mechanisms, clinical results, insights on gene-environment interactions and the role of diet. J Assist Reprod Genet 2016;33:1633-48.

156. Beard JL. Iron biology in immune function, muscle metabolism and neuronal functioning. J Nutr 2001;131:568S-79S; discussion 80S.

157. Reubinoff BE, Har-El R, Kitrossky N, et al. Increased levels of redox-active iron in follicular fluid: a possible cause of free radical-mediated infertility in betathalassemia major. Am J Obstet Gynecol 1996;174:914-8.

158. Nikolaev AA, Lutskii DL, Nikolaeva NN, et al. Iron and nonheme iron protein metabolism in ejaculates with varying degrees of fertility. Urol Nefrol (Mosk) 1998;(5):27-31.

159. Wise T, Lunstra DD, Rohrer GA, et al. Relationships of testicular iron and ferritin concentrations with testicular weight and sperm production in boars. J Anim Sci 2003;81:503-11. 
160. Toebosch AM, Kroos MJ, Grootegoed JA. Transport of transferrin-bound iron into rat Sertoli cells and spermatids. Int J Androl 1987;10:753-64.

161.Lieu PT, Heiskala M, Peterson PA, et al. The roles of iron in health and disease. Mol Aspects Med 2001;22:1-87.

162. Hales KG. Iron testes: sperm mitochondria as a context for dissecting iron metabolism. BMC Biol 2010;8:79.

163.Jacobs EM, Hendriks JC, van Deursen CT, et al. Severity of iron overload of proband determines serum ferritin levels in families with HFE-related hemochromatosis: the HEmochromatosis FAmily Study. J Hepatol 2009;50:174-83.

164.Ammar O, Houas Z, Mehdi M. The association between iron, calcium, and oxidative stress in seminal plasma and sperm quality. Environ Sci Pollut Res Int 2019;26:14097-105.

165. Anderson D, Schmid TE, Baumgartner A. Male-mediated developmental toxicity. Asian J Androl 2014;16:81-8.

166. Uitz PM, Hartleb S, Schaefer S, et al. Pituitary function in patients with hereditary haemochromatosis. Horm Metab Res 2013;45:54-61.

167.Lucesoli F, Fraga CG. Oxidative damage to lipids and DNA concurrent with decrease of antioxidants in rat testes after acute iron intoxication. Arch Biochem Biophys 1995;316:567-71.

168. Verma A, Kanwar KC. Human sperm motility and lipid peroxidation in different ascorbic acid concentrations: an in vitro analysis. Andrologia 1998;30:325-9.

169. Teucher B, Olivares M, Cori H. Enhancers of iron absorption: ascorbic acid and other organic acids. Int J Vitam Nutr Res 2004;74:403-19.

170. Peacock M. Calcium metabolism in health and disease. Clin J Am Soc Nephrol 2010;5 Suppl 1:S23-30.

171. Uhland AM, Kwiecinski GG, DeLuca HF. Normalization of serum calcium restores fertility in vitamin D-deficient male rats. J Nutr 1992;122:1338-44.

172.Ensembl. rs7041 2020. Available online: http:// useast.ensembl.org/Homo_sapiens/Variation/ Explore? $\mathrm{r}=4: 71752117-71753117 ; \mathrm{v}=\mathrm{rs} 7041 ; \mathrm{vdb}=$ variation; $\mathrm{vf}=64610370$

173.Ensembl. rs4588 2020. Available online: http:// useast.ensembl.org/Homo_sapiens/Variation/ Explore? $\mathrm{r}=4: 71752106-71753106 ; \mathrm{v}=\mathrm{rs} 4588 ; \mathrm{vdb}=$ variation; $\mathrm{vf}=64605711$

174. Schuh K, Cartwright EJ, Jankevics E, et al. Plasma membrane $\mathrm{Ca} 2+$ ATPase 4 is required for sperm motility and male fertility. J Biol Chem 2004;279:28220-6.

175. Colagar AH, Marzony ET, Chaichi MJ. Zinc levels in seminal plasma are associated with sperm quality in fertile and infertile men. Nutr Res 2009;29:82-8.

176. Yoshida M, Kawano N, Yoshida K. Control of sperm motility and fertility: diverse factors and common mechanisms. Cell Mol Life Sci 2008;65:3446-57.

177. Kavanagh JP. Sodium, potassium, calcium, magnesium, zinc, citrate and chloride content of human prostatic and seminal fluid. J Reprod Fertil 1985;75:35-41.

178.Johnson LE, DeLuca HF. Vitamin D receptor null mutant mice fed high levels of calcium are fertile. J Nutr 2001;131:1787-91.

179. Wolters VM, Wijmenga C. Genetic background of celiac disease and its clinical implications. Am J Gastroenterol 2008;103:190-5.

180. Sapone A, Lammers KM, Casolaro V, et al. Divergence of gut permeability and mucosal immune gene expression in two gluten-associated conditions: celiac disease and gluten sensitivity. BMC Med 2011;9:23.

181.Jabri B, Sollid LM. Mechanisms of disease: immunopathogenesis of celiac disease. Nat Clin Pract Gastroenterol Hepatol 2006;3:516-25.

182. Bouziat R, Hinterleitner R, Brown JJ, et al. Reovirus infection triggers inflammatory responses to dietary antigens and development of celiac disease. Science 2017;356:44-50.

183. Caminero A, Galipeau HJ, McCarville JL, et al. Duodenal Bacteria From Patients With Celiac Disease and Healthy Subjects Distinctly Affect Gluten Breakdown and Immunogenicity. Gastroenterology 2016;151:670-83.

184.Ludvigsson JF, Leffler DA, Bai JC, et al. The Oslo definitions for coeliac disease and related terms. Gut 2013;62:43-52.

185.Lasa JS, Zubiaurre I, Soifer LO. Risk of infertility in patients with celiac disease: a meta-analysis of observational studies. Arq Gastroenterol 2014;51:144-50.

186. Freeman HJ. Reproductive changes associated with celiac disease. World J Gastroenterol 2010;16:5810-4.

187.Zugna D, Richiardi L, Akre O, et al. Celiac disease is not a risk factor for infertility in men. Fertil Steril 2011;95:170913.e1-3.

188. Lohi S, Lohi O, Vierula M, et al. Coeliac disease autoantibodies in seminal plasma from cases with screen-detected coeliac disease. Scand J Gastroenterol 2009;44:509-11.

189. Green JR, Goble HL, Edwards CR, et al. Reversible insensitivity to androgens in men with untreated gluten enteropathy. Lancet 1977;1:280-2.

190.Aiman J, Griffin JE, Gazak JM, et al. Androgen 
insensitivity as a cause of infertility in otherwise normal men. N Engl J Med 1979;300:223-7.

191. Baker PG, Read AE. Reversible infertility in male coeliac patients. BMJ 1975;2:316-7.

192. Ozgör B, Selimoğlu MA. Coeliac disease and reproductive disorders. Scand J Gastroenterol 2010;45:395-402.

193. Stantiall SE, Serventi L. Nutritional and sensory challenges of gluten-free bakery products: a review. Int J Food Sci Nutr 2018;69:427-36.

194. Shepherd SJ, Gibson PR. Nutritional inadequacies of the gluten-free diet in both recently-diagnosed and longterm patients with coeliac disease. J Hum Nutr Diet 2013;26:349-58.

195. Palatini P, Ceolotto G, Ragazzo F, et al. CYP1A2 genotype modifies the association between coffee intake and the risk of hypertension. J Hypertens 2009;27:1594-601.

196. Ensembl. rs762551 2020. Available online: http:// useast.ensembl.org/Homo_sapiens/Variation/ Population? $\mathrm{r}=15: 74749076-74750076 ; \mathrm{v}=\mathrm{rs} 762551 ; \mathrm{vdb}=\mathrm{var}$ iation; $\mathrm{vf}=15864560$

197. Goldstein A, Warren R. Passage of caffeine into human gonadal and fetal tissue. Biochem Pharmacol 1962;11:166-8.

198. Beach CA, Bianchine JR, Gerber N. The excretion of caffeine in the semen of men: pharmacokinetics and comparison of the concentrations in blood and semen. J Clin Pharmacol 1984;24:120-6.

199. Ricci E, Vigano P, Cipriani S, et al. Coffee and caffeine intake and male infertility: a systematic review. Nutr J 2017;16:37.

200.Klonoff-Cohen H, Bleha J, Lam-Kruglick P. A prospective study of the effects of female and male caffeine consumption on the reproductive endpoints of IVF and gamete intra-Fallopian transfer. Hum Reprod 2002;17:1746-54.

201. Sobreiro BP, Lucon AM, Pasqualotto FF, et al. Semen analysis in fertile patients undergoing vasectomy: reference values and variations according to age, length of sexual abstinence, seasonality, smoking habits and caffeine intake. Sao Paulo Med J 2005;123:161-6.

202. Horak S, Polanska J, Widlak P. Bulky DNA adducts in human sperm: relationship with fertility, semen quality, smoking, and environmental factors. Mutat Res 2003;537:53-65.

203. Killick S, Trussell J, Cleland K, et al. Factors associated with subfertility among women attending an antenatal clinic in Hull. Hum Fertil (Camb) 2009;12:191-7.

204.Jensen TK, Henriksen TB, Hjollund NH, et al. Caffeine intake and fecundability: a follow-up study among 430 Danish couples planning their first pregnancy. Reprod Toxicol 1998;12:289-95.

205. Florack EI, Zielhuis GA, Rolland R. Cigarette smoking, alcohol consumption, and caffeine intake and fecundability. Prev Med 1994;23:175-80.

206. Williams C. Dietary fatty acids and human health. Ann Zootech 2000;49:165-80.

207. Katsuki A, Sumida Y, Urakawa H, et al. Increased oxidative stress is associated with serum levels of triglyceride, insulin resistance, and hyperinsulinemia in Japanese metabolically obese, normal-weight men. Diabetes Care 2004;27:631-2.

208. Park K, Gross M, Lee DH, et al. Oxidative stress and insulin resistance: the coronary artery risk development in young adults study. Diabetes Care 2009;32:1302-7.

209. Sallmén M, Sandler DP, Hoppin JA, et al. Reduced fertility among overweight and obese men. Epidemiology 2006;17:520-3.

210. Melis M, Sollai G, Muroni P, et al. Associations between orosensory perception of oleic acid, the common single nucleotide polymorphisms (rs1761667 and rs1527483) in the CD36 gene, and 6-n-propylthiouracil (PROP) tasting. Nutrients 2015;7:2068-84.

211. Ramos-Lopez O, Panduro A, Martinez-Lopez E, et al. Genetic Variant in the CD36 Gene (rs1761667) is Associated with Higher Fat Intake and High Serum Cholesterol among the Population of West Mexico. J Nutr Food Sci 2015;5:2.

212. Grodstein F, Goldman MB, Cramer DW. Body mass index and ovulatory infertility. Epidemiology 1994;5:247-50.

213. Kasturi SS, Tannir J, Brannigan RE. The metabolic syndrome and male infertility. J Androl 2008;29:251-9.

214. Rato L, Alves MG, Dias TR, et al. High-energy diets may induce a pre-diabetic state altering testicular glycolytic metabolic profile and male reproductive parameters. Andrology 2013;1:495-504.

215. Liu CY, Chou YC, Lin SH, et al. Serum lipid profiles are associated with semen quality. Asian J Androl 2017;19:633-8.

216. Liu F, Li Z, Lv X, et al. Dietary n-3 polyunsaturated fatty acid intakes modify the effect of genetic variation in fatty acid desaturase 1 on coronary artery disease. PLoS One 2015;10:e0121255.

217. Schaeffer L, Gohlke H, Muller M, et al. Common genetic variants of the FADS1 FADS2 gene cluster and their reconstructed haplotypes are associated with the fatty acid composition in phospholipids. Hum Mol Genet 2006; $15: 1745-56$. 
218. Horiguchi S, Nakayama K, Iwamoto S, et al. Associations between a fatty acid desaturase gene polymorphism and blood arachidonic acid compositions in Japanese elderly. Prostaglandins Leukot Essent Fatty Acids 2016;105:9-14.

219.Agarwal A, Makker K, Sharma R. Clinical relevance of oxidative stress in male factor infertility: an update. Am J Reprod Immunol 2008;59:2-11.

220.Zalata AA, Christophe AB, Depuydt CE, et al. The fatty acid composition of phospholipids of spermatozoa from infertile patients. Mol Hum Reprod 1998;4:111-8.

221. Martínez-Soto JC, Landeras J, Gadea J. Spermatozoa and seminal plasma fatty acids as predictors of cryopreservation success. Andrology 2013;1:365-75.

222. Safarinejad MR. Effect of omega-3 polyunsaturated fatty acid supplementation on semen profile and enzymatic anti-oxidant capacity of seminal plasma in infertile men with idiopathic oligoasthenoteratospermia: a doubleblind, placebo-controlled, randomised study. Andrologia 2011;43:38-47.

223. Mendeluk GR, Cohen MI, Ferreri C, et al. Nutrition and Reproductive Health: Sperm versus Erythrocyte Lipidomic Profile and omega-3 Intake. J Nutr Metab 2015;2015:670526.

224. Martínez-Soto JC, Domingo JC, Cordobilla B, et al. Dietary supplementation with docosahexaenoic acid (DHA) improves seminal antioxidant status and decreases sperm DNA fragmentation. Syst Biol Reprod Med 2016;62:387-95.

225.Falsig AL, Gleerup CS, Knudsen UB. The influence of omega-3 fatty acids on semen quality markers: a systematic PRISMA review. Andrology 2019;7:794-803.

226. Ward KD, Sparrow D, Vokonas PS, et al. The relationships of abdominal obesity, hyperinsulinemia and saturated fat intake to serum lipid levels: the Normative Aging Study. Int J Obes Relat Metab Disord 1994;18:137-44.

227. Shaaker M, Rahimipour A, Nouri M, et al. Fatty acid composition of human follicular fluid phospholipids and fertilization rate in assisted reproductive techniques. Iran Biomed J 2012;16:162-8.

228.Jensen TK, Heitmann BL, Blomberg Jensen M, et al. High dietary intake of saturated fat is associated with reduced semen quality among 701 young Danish men from the general population. Am J Clin Nutr 2013;97:411-8.

229. Afeiche MC, Williams PL, Gaskins AJ, et al. Meat intake and reproductive parameters among young men. Epidemiology 2014;25:323-30.

230. Eslamian G, Amirjannati N, Rashidkhani B, et al. Dietary fatty acid intakes and asthenozoospermia: a case-control study. Fertil Steril 2015;103:190-8.

231. Afeiche M, Williams PL, Mendiola J, et al. Dairy food intake in relation to semen quality and reproductive hormone levels among physically active young men. Hum Reprod 2013;28:2265-75.

232. Eslamian G, Amirjannati N, Rashidkhani B, et al. Intake of food groups and idiopathic asthenozoospermia: a casecontrol study. Hum Reprod 2012;27:3328-36.

233. Aitken RJ, Irvine DS, Wu FC. Prospective analysis of sperm-oocyte fusion and reactive oxygen species generation as criteria for the diagnosis of infertility. Am J Obstet Gynecol 1991;164:542-51.

234. Sebastian SM, Selvaraj S, Aruldhas MM, et al. Pattern of neutral and phospholipids in the semen of normospermic, oligospermic and azoospermic men. J Reprod Fertil 1987;79:373-8.

235. Aitken RJ, Clarkson JS, Hargreave TB, et al. Analysis of the relationship between defective sperm function and the generation of reactive oxygen species in cases of oligozoospermia. J Androl 1989;10:214-20.

236. Flesch FM, Gadella BM. Dynamics of the mammalian sperm plasma membrane in the process of fertilization. Biochim Biophys Acta 2000;1469:197-235.

237.U.S. Department of Health and Human Services and U.S. Department of Agriculture. 2015-2020 Dietary Guidelines for Americans. 8th ed. Available online: http://health.gov/ dietaryguidelines/2015/guidelines/2015

238. Malik VS, Popkin BM, Bray GA, et al. Sugar-sweetened beverages, obesity, type 2 diabetes mellitus, and cardiovascular disease risk. Circulation 2010;121:1356-64.

239.Pasquali R, Gambineri A. Metabolic effects of obesity on reproduction. Reprod Biomed Online 2006;12:542-51.

240.Du Plessis SS, Cabler S, McAlister DA, et al. The effect of obesity on sperm disorders and male infertility. Nat Rev Urol 2010;7:153-61.

241. Bener A, Al-Ansari AA, Zirie M, et al. Is male fertility associated with type 2 diabetes mellitus? Int Urol Nephrol 2009;41:777-84.

242. Whitworth KW, Baird DD, Stene LC, et al. Fecundability among women with type 1 and type 2 diabetes in the Norwegian Mother and Child Cohort Study. Diabetologia 2011;54:516-22.

243.Jensen TK, Swan SH, Skakkebaek NE, et al. Caffeine intake and semen quality in a population of 2,554 young Danish men. Am J Epidemiol 2010;171:883-91.

244. Ruff JS, Suchy AK, Hugentobler SA, et al. Humanrelevant levels of added sugar consumption increase female mortality and lower male fitness in mice. Nat Commun 
2013;4:2245.

245. Liu CY, Chou YC, Chao JC, et al. The Association between Dietary Patterns and Semen Quality in a General Asian Population of 7282 Males. PLoS One 2015;10:e0134224.

246. Agarwal A, Said TM. Oxidative stress, DNA damage and apoptosis in male infertility: a clinical approach. BJU Int 2005;95:503-7.

247. Vine MF, Setzer RW Jr, Everson RB, et al. Human sperm morphometry and smoking, caffeine, and alcohol consumption. Reprod Toxicol1997;11:179-84.

248. InterAct Consortium. Dietary fibre and incidence of type 2 diabetes in eight European countries: the EPICInterAct Study and a meta-analysis of prospective studies. Diabetologia 2015;58:1394-408.

249. Brennan CS. Dietary fibre, glycaemic response, and diabetes. Mol Nutr Food Res 2005;49:560-70.

250.Aune D, Norat T, Romundstad P, et al. Whole grain and refined grain consumption and the risk of type 2 diabetes: a systematic review and dose-response meta-analysis of cohort studies. Eur J Epidemiol 2013;28:845-58.

251.Ding GL, Liu Y, Liu ME, et al. The effects of diabetes on male fertility and epigenetic regulation during

Cite this article as: Vanderhout SM, Rastegar Panah M, Garcia-Bailo B, Grace-Farfaglia P, Samsel K, Dockray J, Jarvi K, El-Sohemy A. Nutrition, genetic variation and male fertility. Transl Androl Urol 2021;10(3):1410-1431. doi: 10.21037/tau-20592 spermatogenesis. Asian J Androl 2015;17:948-53.

252. Rama Raju GA, Jaya Prakash G, Murali Krishna K, et al. Noninsulin-dependent diabetes mellitus: effects on sperm morphological and functional characteristics, nuclear DNA integrity and outcome of assisted reproductive technique. Andrologia 2012;44 Suppl 1:490-8.

253.La Vignera S, Condorelli RA, Vicari E, et al. High levels of lipid peroxidation in semen of diabetic patients. Andrologia 2012;44 Suppl 1:565-70.

254. Gaskins AJ, Colaci DS, Mendiola J, et al. Dietary patterns and semen quality in young men. Hum Reprod 2012;27:2899-907.

255. Goodrich JK, Waters JL, Poole AC, et al. Human genetics shape the gut microbiome. Cell 2014;159:789-99.

256. Gibbons SM, Kearney SM, Smillie CS, et al. Two dynamic regimes in the human gut microbiome. PLoS Comput Biol 2017;13:e1005364.

257.Le Chatelier E, Nielsen T, Qin J, et al. Richness of human gut microbiome correlates with metabolic markers. Nature 2013;500:541-6.

258. Mor A, Driggers PH, Segars JH. Molecular characterization of the human microbiome from a reproductive perspective. Fertil Steril 2015;104:1344-50. 